\title{
DESAIN INSTALASI PENGOLAHAN AIR LIMBAH INDUSTRI PT NATURA PERISA AROMA LAMPUNG
}

\author{
Yosep Widi Nugraha dan Setiyono \\ Pusat Teknologi Lingkungan, BPPT, Kawasan Puspiptek, Tangerang Selatan, 15314, Indonesia \\ Email: yosep.widi@bppt.go.id
}

\begin{abstract}
ABSTRAK
PT Natura Perisa Aroma Lampung Selatan merupakan salah satu perusahaan yang bekerja di bidang industri bahan makanan. Di dalam kegiatannya, PT Natura Perisa Aroma yang berlokasi di Insinyur Sutami KM 9 Sukanegara, Kecamatan Tanjung Bintang Kali Asin, Tj. Bintang, Kabupaten Lampung Selatan membuka pabrik baru yaitu Unit Minyak Atsiri dengan bahan baku pala, cengkeh, kayu manis, sereh wangi dan lada hitam. Dengan adanya unit pabrik baru ini, akan membutuhkan unit pengolahan air limbah produksi yang berbeda dari pabrik yang lama. Hal ini dikarenakan perbedaan karakteristik air limbah yang dihasilkan dan kapasitas produksi yang membutuhkan unit IPAL yang baru. Limbah cair yang dihasilkan dari unit minyak atsiri masih mengandung sisa minyak dan organik tinggi, bersifat asam dan suhunya tinggi sehingga untuk pengolahannya memerlukan unit pretreatment berupa bak pengumpul penurun suhu, unit pemisah minyak (oil trap) dan unit netralisasi. Instalasi Pengolahan Air Limbah (IPAL) PT Natura Perisa Aroma unit minyak atsiri menggunakan reaktor aerobik menggunakan lumpur aktif. Pengolahan air limbah menggunakan lumpur aktif ini dapat menguraikan senyawa organik dalam air limbah melalui proses biologi menggunakan mikroorganisme. Outlet IPAL PT Natura Perisa Aroma harus memenuhi baku mutu sesuai Permen LH RI No. 5 tahun 2014 Lampiran XLVII tentang Baku Mutu Air Limbah bagi Usaha Dan/atau Kegiatan Yang Belum Memiliki Baku Mutu Air Limbah Yang Ditetapkan.
\end{abstract}

Kata kunci : air limbah produksi, karakteristik limbah, unit pretreatment, baku mutu

\section{DESIGN OF INDUSTRIAL WASTEWATER TREATMENT PLANT PT NATURA PERISA AROMA LAMPUNG}

\author{
Yosep Widi Nugraha dan Setiyono \\ Center for Environmental Technology, BPPT, Puspiptek Area, South Tangerang, 15314, Indonesia \\ Email: yosep.widi@bppt.go.id
}

\begin{abstract}
PT Natura Perisa Aroma South Lampung is one company that works in the food industry. PT Natura Perisa Aroma located in Sutami Engineer KM 9 Sukanegara, Tanjung Bintang Kali Asin District, Tj. Bintang, South Lampung Regency, opened a new factory, the Essential Oil Unit with raw materials of nutmeg, cloves, cassia, citronella and black pepper. With the existence of this new plant unit, it will require a different production wastewater treatment unit from the other factories. This is due to differences in the characteristics of the resulting wastewater and production capacity which requires a new WWTP unit. The wastewater produced from the essential oil unit still contains high oil and organic residues, is acidic and high in temperature so that the processing requires a pretreatment unit in the form of a temperaturelowering collector, oil trap unit and neutralization unit. PT Natura Perisa Aroma's Waste Water Treatment Plant (WWTP), an essential oil unit, uses an aerobic reactor using activated sludge. Wastewater treatment using activated sludge can decompose organic compounds in waste water through the biological process using microorganisms. PT Natura Perisa Aroma IPAL outlet must meet the quality standards in accordance with Permen LH RI No. 5 tahun 2014 Lampiran XLVII tentang Baku Mutu Air Limbah bagi Usaha Dan/atau Kegiatan Yang Belum Memiliki Baku Mutu Air Limbah Yang Ditetapkan
\end{abstract}

Keywords : industry wastewater, wastewater characteristics, pretreatment system, standards quality. 


\section{PENDAHULUAN}

\subsection{Latar Belakang}

Masalah pencemaran lingkungan oleh air limbah saat ini sudah sampai pada tahap yang mengkhawatirkan, khususnya di kota-kota besar seperti Jakarta, Surabaya, Medan, dan sebagainya. Beban polutan organik yang dibuang ke badan sungai atau lingkungan sudah di luar daya dukung lingkungan, yaitu pada tahap dimana alam atau lingkungan sudah tidak mampu lagi melakukan penguraian secara alami.

Secara garis besar air limbah yang dihasilkan dari aktifitas manusia dapat digolongkan menjadi 2 jenis, yaitu air limbah industri dan air limbah domestik. Air limbah industri adalah air limbah yang dihasilkan dari proses produksi yang ada di kegiatan suatu industri manufaktur atau pabrik. Sedangkan air limbah domestik adalah air limbah yang dihasilkan dari aktifitas manusia sehari-hari meliputi dari toilet, dapur dan kantin, kamar mandi dan air pencucian pakaian.

Air limbah dari industri maupun domestik sebelum dibuang harus dilakukan proses pengolahan terlebih dahulu dan cara pengolahannya pun perlu disesuaikan dengan karakteristik dari polutan yang ada pada limbah tersebut. Pengolahan air limbah bertujuan untuk menghilangkan parameter pencemar yang ada di dalam air limbah sampai batas yang diperbolehkan untuk dibuang ke badan air sesuai dengan syarat baku mutu yang diijinkan.

PT. Natura Perisa Aroma Lampung merupakan sebuah perusahaan terkemuka dalam pengolahan bumbu dan rempah yang berlokasi di Jl. Ir. Sutami KM. 9 di desa Sukanegara yang merupakan kawasan industri bagi Kota Lampung Selatan. Pabrik PT Natura Perisa Aroma berdiri di atas tanah seluas $2000 \mathrm{~m}^{2}$ yang meliputi bangunan kantor, pabrik, gudang, bengkel, dan mushola untuk karyawan. Sisi sebelah kanan pabrik adalah gudang jagung sedangkan sisi kirinya adalah bukit berbatu yang separuhnya sudah dipotong.

Saat ini PT. Natura Perisa Aroma sedang malakukan pengembangan usaha dan/atau kegiatan dengan melakukan pembangunan unit produksi baru untuk produksi minyak atsiri. Terkait proyek pembangunan unit produksi baru tersebut juga dilakukan desain dan konstruksi Instalasi Pengolahan Air Limbah (IPAL) dengan kapasitas $20 \mathrm{~m}^{3} /$ hari.

\subsection{Permasalahan}

Dalam melakukan aktifitasnya, PT. Natura Perisa Aroma ini akan menggunakan air tanah untuk kebutuhan domestik maupun untuk kebutuhan air proses produksi, sehingga industri ini menghasilkan air limbah yang harus diolah agar tidak mencemari lingkungan. Secara garis besar, air limbah yang dihasilkan oleh PT. Natura Perisa Aroma berdasarkan karakteristiknya dapat dikelompokkan menjadi dua jenis, yaitu air limbah domestik dan air limbah produksi.

Pada prinsipnya, untuk menangani kedua jenis air limbah ini jelas diperlukan teknologi yang berlainan, sehingga kedua jenis limbah harus dikelola secara terpisah sesuai dengan sifatsifatnya. Jika penanganan kedua jenis limbah ini langsung disatukan tanpa melakukan pretreatment terlebih dahulu, maka dapat menimbulkan berbagai masalah dalam proses pengolahan, bahkan sangat dimungkinkan hasil pengolahannya tidak seperti yang diharapkan.

PT Natura Perisa Aroma berencana melakukan desain dan pembangunan IPAL untuk mengolah air limbah industri yang dihasilkan dari pabrik produksi minyak atsiri yang sedang dibangun. Pelaksanaan desain IPAL industri dan pembangunannya dilakukan secara paralel, sehingga pada saat pabrik mulai beroperasi sudah memiliki unit sistem IPAL untuk mengolah air limbahnya. IPAL yang dirancang harus memiliki kapasitas yang mencukupi untuk mengolah air limbah dari proses produksi dan hasil pengolahannya harus dapat memenuhi baku mutu buangan limbah industri sesuai dengan Permen LH RI No. 5 tahun 2014 Lampiran XLVII tentang Baku Mutu Air Limbah bagi Usaha Dan/atau Kegiatan Yang Belum Memiliki Baku Mutu Air Limbah Yang Ditetapkan. Baku mutu tersebut dapat ditunjukkan dalam Tabel 1 berikut:

Tabel 1. Baku Mutu Air Limbah bagi Usaha

Dan/atau Kegiatan Yang Belum Memiliki Baku Mutu Air Limbah Yang Ditetapkan

\begin{tabular}{|c|c|c|c|}
\hline \multirow{2}{*}{ Parameter } & \multirow{2}{*}{ Satuan } & \multicolumn{2}{|c|}{ Golongan } \\
\hline & & I & II \\
\hline Temperatur & ${ }^{\circ} \mathrm{C}$ & 38 & 40 \\
\hline Zat Padat Terlarut & $\mathrm{mg} / \mathrm{L}$ & 2.000 & 4.000 \\
\hline Zat Padat Suspensi & $\mathrm{mg} / \mathrm{L}$ & 200 & 400 \\
\hline $\mathrm{pH}$ & - & $6-9$ & $6-9$ \\
\hline Besi Terlarut (Fe) & $\mathrm{mg} / \mathrm{L}$ & 5 & 10 \\
\hline Mangan Terlarut (Mn) & $\mathrm{mg} / \mathrm{L}$ & 2 & 5 \\
\hline Barium $(\mathrm{Ba})$ & $\mathrm{mg} / \mathrm{L}$ & 2 & 3 \\
\hline Tembaga (Cu) & $\mathrm{mg} / \mathrm{L}$ & 2 & 3 \\
\hline Seng $(Z n)$ & $\mathrm{mg} / \mathrm{L}$ & 5 & 10 \\
\hline Krom Heksavalen & $\mathrm{mg} / \mathrm{L}$ & 0,1 & 0,5 \\
\hline Krom Total (Cr) & $\mathrm{mg} / \mathrm{L}$ & 0,5 & 1 \\
\hline Cadmium (Cd) & $\mathrm{mg} / \mathrm{L}$ & 0,05 & 0,1 \\
\hline Air Raksa $(\mathrm{Hg})$ & $\mathrm{mg} / \mathrm{L}$ & 0,002 & 0,005 \\
\hline Timbal $(\mathrm{Pb})$ & $\mathrm{mg} / \mathrm{L}$ & 0,12 & 1 \\
\hline Stanum (SN) & $\mathrm{mg} / \mathrm{L}$ & 0,1 & 3 \\
\hline Arsen (As) & $\mathrm{mg} / \mathrm{L}$ & 0,1 & 0,5 \\
\hline Selenium (Se) & $\mathrm{mg} / \mathrm{L}$ & 0,05 & 0,5 \\
\hline Nikel (Ni) & $\mathrm{mg} / \mathrm{L}$ & 0,2 & 0,5 \\
\hline Kobalt (Co) & $\mathrm{mg} / \mathrm{L}$ & 0,4 & 0,6 \\
\hline Sianida $(\mathrm{CN})$ & $\mathrm{mg} / \mathrm{L}$ & 0,05 & 0,5 \\
\hline Sulfida $\left(\mathrm{H}_{2} \mathrm{~S}\right)$ & $\mathrm{mg} / \mathrm{L}$ & 0,5 & 1 \\
\hline Fluorida $(F)$ & $\mathrm{mg} / \mathrm{L}$ & 2 & 3 \\
\hline Klorin Bebas $\left(\mathrm{Cl}_{2}\right)$ & $\mathrm{mg} / \mathrm{L}$ & 1 & 2 \\
\hline
\end{tabular}




\begin{tabular}{l|c|c|c}
\hline \multirow{2}{*}{ Parameter } & \multirow{2}{*}{ Satuan } & \multicolumn{2}{c}{ Golongan } \\
\cline { 3 - 4 } & & I & II \\
\hline Amonia-Nitrogen & $\mathrm{mg} / \mathrm{L}$ & 5 & 10 \\
\hline Nitrat & $\mathrm{mg} / \mathrm{L}$ & 20 & 30 \\
\hline Nitrit & $\mathrm{mg} / \mathrm{L}$ & 1 & 3 \\
\hline Total Nitrogen & $\mathrm{mg} / \mathrm{L}$ & 30 & 60 \\
\hline BOD & $\mathrm{mg} / \mathrm{L}$ & 50 & 150 \\
\hline COD & $\mathrm{mg} / \mathrm{L}$ & 100 & 300 \\
\hline Senyawa Aktif Biru & $\mathrm{mg} / \mathrm{L}$ & 5 & 10 \\
Metilen & $\mathrm{mg} / \mathrm{L}$ & 0,5 & 1 \\
\hline Fenol & $\mathrm{mg} / \mathrm{L}$ & 10 & 20 \\
\hline Minyak dan Lemak & $\mathrm{MPN}$ & \multicolumn{2}{|c}{10.000} \\
\hline Total Koliform & $/ 100 \mathrm{~mL}$ & \multicolumn{2}{|c}{} \\
\hline
\end{tabular}

Sumber: Permen LH RI No. 5 tahun 2014 Lampiran XLVII

Dalam Permen LH RI No. 5 tahun 2014 tidak menyebutkan jenis industri minyak atsiri di dalam baku mutu air limbah, sehingga air limbah yang dihasilkan PT Natura Perisa Aroma merujuk pada lampiran XLVII yaitu baku mutu air limbah bagi usaha dan/atau kegiatan yang belum memiliki baku mutu air limbah yang ditetapkan. Di dalam tabel lampiran IV terdapat dua baku mutu air limbah yang dibedakan dari golongan industrinya. Jika air limbah yang dibuang ke badan air penerima sungai kelas I, maka usaha dan/atau kegiatan tersebut mengikuti baku mutu air limbah golongan I dan jika kandungan BOD kurang dari 1.500 ppm dan COD kurang dari 3.000 ppm pada air limbah sebelum dilakukan pengolahan, maka diberlakukan baku mutu air limbah golongan I. Baku mutu air limbah golongan II jika kandungan BOD lebih dari 1.500 ppm dan/atau COD lebih dari 3.000 ppm pada air limbah sebelum dilakukan pengolahan dan badan air penerimanya bukan sungai kelas I. Limbah PT Natura Perisa Aroma termasuk dalam golongan II karena kandungan $\mathrm{BOD}$ dan $\mathrm{COD}$ masih kurang dari yang dipersyaratkan di Permen LH. Dalam perancangan IPAL PT Natura Perisa Aroma akan didesain mengikuti ketentuan baku mutu air limbah golongan I tersebut.

\subsection{Tujuan dan Sasaran}

Tujuan perancangan dan penelitian ini adalah sebagai berikut:

a. Mengevaluasi sumber limbah industri yang dihasilkan PT Natura Perisa Aroma Lampung

b. Melaksanakan perhitungan kapasitas dan beban IPAL

c. Membuat desain sistem Instalasi Pengolahan Air Limbah (IPAL) industri, start-up serta monitoring terhadap hasil pembangunan IPAL PT Natura Perisa Aroma

Sasaran yang akan dicapai adalah terbangunnya satu unit IPAL industri PT Natura
Perisa Aroma yang dapat menghasilkan outlet limbah yang dapat memenuhi standar baku mutu buangan air limbah industri sesuai dengan yang dipersyaratkan.

\subsection{Metodologi}

Metodologi pelaksanaan kegiatan ini adalah sebagai berikut:

a. Survei lapangan mengenai keadaan lokasi calon IPAL PT Natura Perisa Aroma meliputi lokasi IPAL, keadaan tanah, utility dan kebutuhan air bersih IPAL.

b. Observasi lapangan dan pengambilan datadata sekunder.

c. Pengumpulan data dengan target mendapatkan data - data sebagai berikut:

- Jumlah limbah yang diolah per hari.

- Karakteristik limbah yang dihasilkan.

d. Perencanaan teknis sistem IPAL

e. Pelaksanaan pembangunan IPAL.

f. Start-up operasional IPAL.

g. Monitoring hasil operasional IPAL.

\subsection{Hasil Yang Diharapkan}

Hasil yang diharapkan dari pekerjaan ini adalah sebagai berikut :

a. Terbangunnya unit sistem pengolahan IPAL industri minyak atsiri PT Natura Perisa Aroma

b. Terpenuhinya standar kualitas air limbah buangan industri golongan I.

\section{PROSES PENGOLAHAN AIR LIMBAH INDUSTRI}

Pengolahan air limbah bertujuan untuk menghilangkan parameter pencemar yang ada di dalam air limbah sampai batas yang diperbolehkan untuk dibuang ke badan air sesuai dengan syarat baku mutu yang diijinkan atau sampai memenuhi kualitas tertentu untuk dimanfaatkan kembali.

Pengolahan air limbah secara garis besar merupakan upaya pemisahan padatan tersuspensi (solid-liquid separation), pemisahan senyawa koloid, serta penghilangan senyawa polutan terlarut. Ditinjau dari jenis prosesnya, pengolahan air limbah dapat dikelompokkan menjadi empat yaitu proses pengolahan secara fisika, proses secara kimia, proses secara fisikakimia serta proses pengolahan secara biologis.

Penerapan masing - masing metode tergantung pada karakteristik limbahnya dan kualitas hasil yang diinginkan. Jika ditinjau dari urutannya proses pengolahan air limbah dapat dibagi menjadi tiga jenis pengolahan, yaitu:

a. Pengolahan Primer, digunakan sebagai pengolahan pendahuluan untuk menghilangkan padatan tersuspensi, 
koloid, serta penetralan yang umumnya menggunakan proses fisika atau proses kimia.

b. Pengolahan Sekunder, digunakan untuk menghilangkan senyawa polutan organik terlarut yang umumnya dilakukan secara proses biologis.

c. Pengolahan Tersier atau Pengolahan Lanjut, digunakan untuk menghasilkan air olahan dengan kualitas yang lebih bagus sesuai dengan yang diharapkan.

Proses pengolahan air limbah dapat dilakukan dengan baik secara biologis, secara fisika, kimia atau kombinasi ke tiga proses tersebut.

\subsection{Pengolahan Air Limbah Secara Fisika- Kimia}

Proses pengolahan air limbah secara fisikakimia meliputi :

\section{a. Proses Penyaringan}

Di dalam proses pengolahan air limbah, saringan dilakukan pada tahap paling awal. Saringan digunakan untuk untuk memisahkan bermacam-macam benda padat yang ada di dalam air limbah, misalnya kertas, plastik, kain, dan benda dari metal serta lainnya. Benda-benda tersebut jika tidak dipisahkan dapat menyebabkan kerusakan pada sistem pemompaan dan unit peralatan pemisah lumpur misalnya weir, block valve, nozzle, flowmeter, saluran serta sistem perpipaan. Hal tersebut dapat menimbulkan masalah yang serius terhadap operasional maupun pemeliharaan peralatan. Saringan yang halus kadang-kadang dapat juga digunakan untuk memisahkan padatan tersuspensi

\section{b. Proses Sedimentasi/ Pengendapan}

Di dalam proses pengolahan air limbah, pasir, kerikil halus, dan juga benda-benda lain misalnya kepingan logam, pecahan kaca, tulang, dan lain lain yang mana tidak dapat membusuk, harus dipisahkan terlebih dahulu. Hal ini dilakukan untuk:

- Melindungi kerusakan pada peralatan mekanik seperti pompa, flowmeter, dll agar tidak terjadi abrasi atau kebuntuan.

- Untuk menjaga atau mencegah kebuntuan di dalam sistem perpipaan dan terjadinya pengendapan di dalam saluran.

- Untuk mencegah pengerakan (cementing) di dasar bak pengendapan awal atau bak pengolah lumpur (sludge digesting).

- Untuk mengurangi atau menghilangkan akumulasi dari material inert yang tidak dapat terurai di dalam bak aerasi atau reaktor biologis serta bak pengolah lumpur yang akan mengakibatkan kerugian volume (loss of usable volume).

\section{c. Proses Separasi Minyak}

Kegiatan penyulingan bahan rempahrempah selain menghasilkan minyak atsiri sebagai produk utama yang akan dijual juga menghasilkan limbah berupa ampas ektraksi yang biasa digunakan untuk kompos atau untuk soil conditioner (perbaikan tanah miskin/rusak) dan cairan ekstraksi. Cairan ekstraksi ini selanjutnya akan dikeluarkan atau dialirkan dari reaktor ekstraksi ke dalam bak pengumpul. Cairan ekstraksi yang dibuang ke bak pengumpul masih mengandung minyak atsiri dan pada umumnya masih memiliki suhu yang tinggi. Minyak yang terlarut di dalam cairan ekstraksi di dalam saluran pembuangan sebagian akan menempel di dalam dinding permukaan pipa saluran air limbah dan sebagian akan terbawa ke bak pengumpul.

Minyak yang menempel di dinding pipa dapat menghambat laju aliran limbah dan bila tidak segera dilakukan penanganan pipa saluran air limbah dapat tersumbat. Adapun minyak yang masuk ke dalam bak pengumpul akan mengganggu proses pengolahan air limbah di IPAL. Untuk mengatasi permasalahan ini maka perlu dilakukan pemisahan lapisan minyak dari air limbah untuk itu sebelum proses biologi di dalam IPAL perlu dibuatkan bak pemisah minyak dan lemak (oil trap).

\section{d. Proses Netralisasi Air Limbah}

$\mathrm{pH}$ adalah derajat keasaman yang digunakan untuk menyatakan tingkat keasaman atau kebasaan yang dimiliki oleh suatu larutan. $\mathrm{pH}$ didefinisikan sebagai kologaritma aktivitasion hidrogen $\left(\mathrm{H}^{+}\right)$yang terlarut. Koefisien aktifitas ion hidrogen tidak dapat diukur secara eksperimental, sehingga nilainya didasarkan pada perhitungan teoritis. Skala pH bukanlah skala absolut. la bersifat relatif terhadap sekumpulan larutan standar yang $\mathrm{pH}$-nya ditentukan berdasarkan persetujuan internasional. Salah satu pengukuran yang sangat penting dalam berbagai cairan proses (industri, farmasi, manufaktur, produksi makanan dan sebagainya) adalah $\mathrm{pH}$, yaitu pengukuran ion hidrogen dalam suatu larutan. Larutan dengan harga $\mathrm{pH}$ rendah dinamakan "asam" sedangkan yang harga $\mathrm{pH}$-nya tinggi dinamakan "basa". Skala $\mathrm{pH}$ rentang dari 0 (asam kuat) sampai 14 (basa kuat) dengan 7 adalah harga tengah mewakili air murni (netral). Nilai ini menunjukkan konsentrasi ion $\mathrm{H}^{+}$dan ion $\mathrm{OH}^{-}$di dalam air. Gambar 1 menunjukkan hubungan antara nilai $\mathrm{pH}$ dengan konsentrasi ion $\mathrm{H}^{+}$dan $\mathrm{OH}^{-}$ 


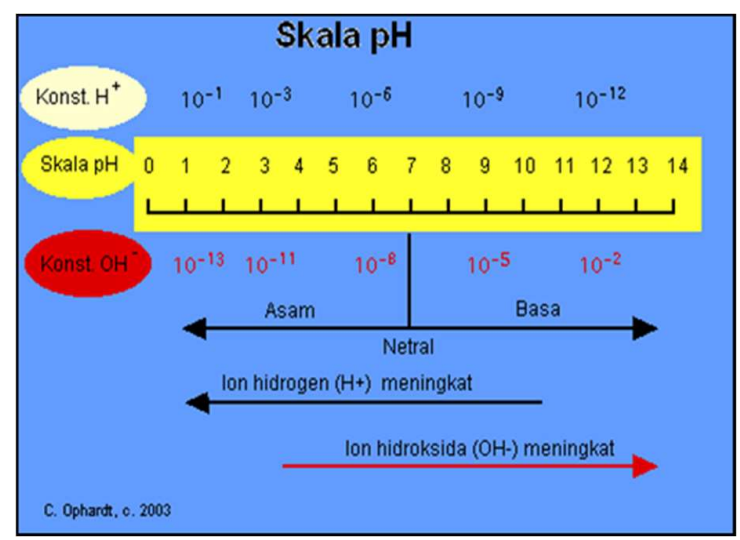

Gambar 1. Hubungan nilai pH Terhadap Konsentrasi $\mathrm{H}^{+}$dan $\mathrm{OH}^{-}$

Prinsip dari skala $\mathrm{pH}$ adalah : Konsentrasi ion $\mathrm{H}^{+}$berhubungan terbalik terhadap nilai $\mathrm{pH}$, sedangkan konsentrasi ion $\mathrm{OH}^{-}$berhubungan langsung terhadap nilai $\mathrm{pH}$.

$\mathrm{pH}$ larutan dapat diukur dengan beberapa cara. Secara kualitatif $\mathrm{pH}$ dapat diperkirakan dengan kertas Lakmus (Litmus) atau suatu indikator (kertas indikator $\mathrm{pH}$ ). Secara kuantitatif pengukuran $\mathrm{pH}$ dapat digunakan elektroda potensiometrik. Elektroda ini memonitor perubahan voltase yang disebabkan oleh perubahan aktifitas ion hidrogen $\left(\mathrm{H}^{+}\right)$dalam larutan.

Elektroda $\mathrm{pH}$ yang paling modern terdiri dari kombinasi tunggal elektroda referensi (reference electrode) dan elektroda sensor (sensing electrode) yang lebih mudah dan lebih murah daripada elektroda tepisah. Elektroda kombinasi ini mempunyai fungsi yang sama dengan elektroda pasangan.

Proses netralisasi bertujuan untuk menetralkan $\mathrm{pH}$ atau keasaman air limbah sampai menjadi netral. Hal ini dimaksudkan agar proses pengolahan air limbah secara biologis dapat berjalan dengan baik. Bahan kimia yang umum digunakan adalah asam sulfat $\left(\mathrm{H}_{2} \mathrm{SO}_{4}\right)$ atau asam khlorida $(\mathrm{HCl})$ untuk menetralkan air limbah yang bersifat alkali. Sedangkan untuk zat alkali yang banyak digunakan antara lain yakni soda ash atau soda abu ( $\left.\mathrm{NaHCO}_{3}\right)$, kapur tohor $(\mathrm{CaO}), \mathrm{Ca}(\mathrm{OH})_{2}$ , $\mathrm{CaCO}_{3}$, natrium hidroksida $(\mathrm{NaOH})$.

Proses penetralan umumnya dilakukan dengan pengadukan di dalam bak pencampur dengan waktu tinggal 5 - 30 menit. Untuk penetralan dengan menggunakan kapur, dapat menimbulkan endapan garam kalsium.

\section{e. Pengeringan/ Pengolahan Lumpur}

Lumpur yang dihasilkan dari proses sedimentasi diolah lebih lanjut untuk mengurangi sebanyak mungkin air yang masih terkandung didalamnya. Proses pengolahan lumpur yang bertujuan mengurangi kadar air tersebut sering disebut dengan pengeringan lumpur. Ada empat cara proses pengurangan kadar air, yaitu secara alamiah, dengan tekanan (pengepresan), dengan gaya sentrifugal dan dengan pemanasan.

Pengeringan secara alamiah dilakukan dengan mengalirkan atau memompa lumpur endapan ke sebuah kolam pengering (drying bed) yang mempunyai luas permukaan yang besar dengan kedalaman sekitar 1 atau 2 meter. Proses pengeringan berjalan dengan alamiah, yaitu dengan panas matahari dan angin yang bergerak di atas kolam pengering lumpur tersebut. Cara pengeringan seperti ini tentu saja sangat bergantung dari cuaca dan akan bermasalah bila terjadi hujan. Bila lumpur tidak mengandung bahan yang berbahaya, maka kolam pengering lumpur dapat hanya berupa galian tanah biasa, sehingga sebagian air akan meresap ke dalam tanah dibawahnya. Contoh pengeringan lumpur antara lain pengeringan lumpur dengan cara tekanan (pengepresan) dan proses pengeringan lumpur dengan gaya centrifugal. Berikut diberikan beberapa contoh alat pengering lumpur yang ada.

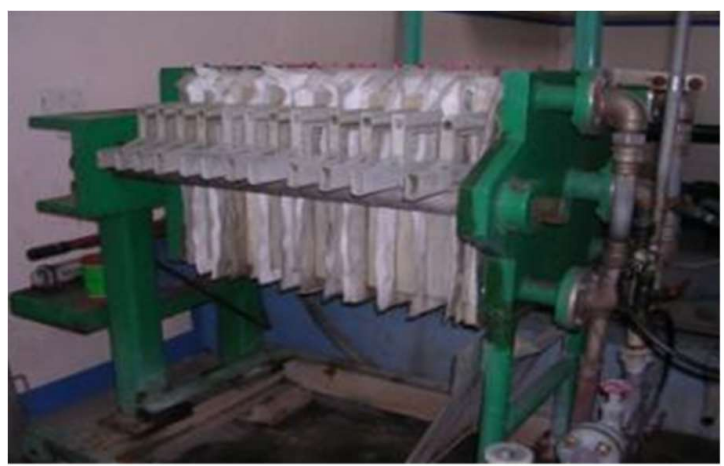

Gambar 2. Unit Pengering Lumpur Dengan Filter Press

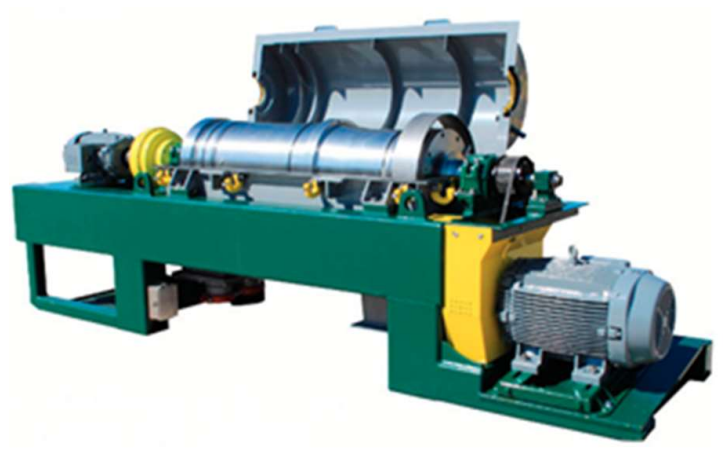

Gambar 3. Unit Centrifugal type decanter / for sludge dehydration KT-1967HD 


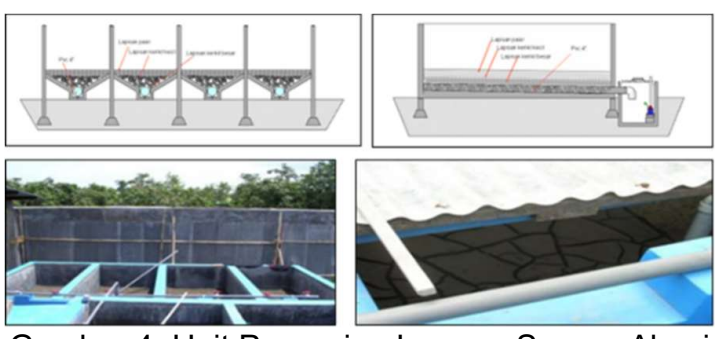

Gambar 4. Unit Pengering Lumpur Secara Alami (Sludge Drying Bed)

\subsection{Pengolahan Air Limbah Secara Biologis}

Untuk mengolah air yang mengandung senyawa organik umumnya menggunakan teknologi pengolahan air limbah secara biologis atau gabungan antara proses biologis dengan proses kimia-fisika. Proses secara biologis tersebut dapat dilakukan pada kondisi aerobik (dengan udara), kondisi anaerobik (tanpa udara) atau kombinasi anaerobik dan aerobik. Proses biologis aerobik biasanya digunakan untuk pengolahan air limbah dengan beban BOD yang tidak terlalu besar, sedangkan proses biologis anaerobik digunakan untuk pengolahan air limbah dengan beban BOD yang sangat tinggi. Pengolahan air limbah secara biologis aerobik secara garis besar dapat dibagi menjadi tiga yakni proses biologis dengan biakan tersuspensi (suspended culture), proses biologis dengan biakan melekat (attached culture) dan proses pengolahan dengan sistem kolam (lagoon).

Proses biologis dengan biakan tersuspensi adalah sistem pengolahan dengan menggunakan aktifitas mikro-organisme untuk menguraikan senyawa polutan yang ada dalam air dan mikroorganime yang digunakan dibiakkan secara tersuspensi di dalam suatu reaktor. Beberapa contoh proses pengolahan dengan sistem ini antara lain: proses lumpur aktif standar/konvensional (standard activated sludge), step aeration, contact stabilization, extended aeration, oxidation ditch (kolam oksidasi sistem parit) dan lainnya.

Proses biologis dengan biakan melekat yakni proses pengolahan air limbah dimana mikro-organisme yang digunakan dibiakkan pada suatu media sehingga mikro-organisme tersebut melekat pada permukaan media. Beberapa contoh teknologi pengolahan air limbah dengan cara ini antara lain : trickling filter atau biofilter, rotating biological contactor (RBC), contact aeration/oxidation (aerasi kontak) dan lainnya

Proses pengolahan air limbah secara biologis dengan lagoon atau kolam adalah dengan menampung air limbah pada suatu kolam yang luas dengan waktu tinggal yang cukup lama sehingga dengan aktifitas mikro-organisme yang tumbuh secara alami, senyawa polutan yang ada dalam air akan terurai. Untuk mempercepat proses penguraian senyawa polutan atau memperpendek waktu tinggal dapat juga dilakukan proses aerasi. Salah satu contoh proses pengolahan air limbah dengan cara ini adalah kolam aerasi atau kolam stabilisasi (stabilization pond). Proses dengan sistem lagoon tersebut kadang-kadang dikategorikan sebagai proses biologis dengan biakan tersuspensi.

Secara garis besar klasifikasi proses pengolahan air limbah secara aerobik dapat dilihat seperti pada Gambar 5, sedangkan karakteristik pengolahan, parameter perencanaan serta efisiensi pengolahan untuk tiap - tiap jenis proses dapat dilihat pada Tabel 2. Untuk memilih jenis teknologi atau proses yang akan digunakan untuk pengolahan air limbah, beberapa hal yang perlu diperhatikan antara lain: karakteristik air limbah, jumlah air limbah serta standar kualitas air olahan yang diharapkan.

KLASIFIKASI PROSES PENGOLAHAN AIR LIMBAH SECARA BIOLOGIS

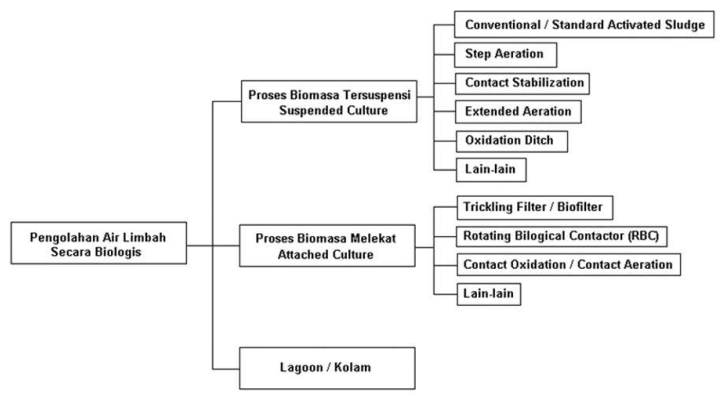

Gambar 5. Klasifikasi proses pengolahan air limbah secara biologis

Tabel 2. Karakterisitik operasional proses pengolahan air limbah dengan proses biologis

\begin{tabular}{|c|c|c|c|}
\hline \multicolumn{2}{|c|}{ JENIS PROSES } & \multirow{2}{*}{$\begin{array}{c}\begin{array}{c}\text { EFISIENSI } \\
\text { PENGHILANGAN } \\
\text { BOD (\%) }\end{array} \\
85-95\end{array}$} & \multirow{2}{*}{$\begin{array}{c}\text { KETERANGAN } \\
-\end{array}$} \\
\hline \multirow{7}{*}{$\begin{array}{l}\text { PROSES } \\
\text { BIOMASA } \\
\text { TERSUSPENSI }\end{array}$} & $\begin{array}{l}\text { Lumpur Aktif } \\
\text { Standar }\end{array}$ & & \\
\hline & Step Aeration & $85-95$ & $\begin{array}{l}\text { Digunakan untuk beban pengolahan } \\
\text { yang besar. }\end{array}$ \\
\hline & $\begin{array}{l}\text { Modified } \\
\text { Aeration }\end{array}$ & $60-75$ & $\begin{array}{l}\text { Untuk pengolahan dengan kualitas } \\
\text { air olahan sedang. }\end{array}$ \\
\hline & $\begin{array}{l}\text { Contact } \\
\text { Stabilization }\end{array}$ & $80-90$ & $\begin{array}{l}\text { Digunakan untuk pengolahan paket. } \\
\text { Untuk mereduksi ekses lumpur. }\end{array}$ \\
\hline & $\begin{array}{l}\text { High Rate } \\
\text { Aeration }\end{array}$ & $75-90$ & $\begin{array}{l}\text { Untuk pengolahan paket, bak aerasi } \\
\text { dan bak pengendap akhir } \\
\text { merupakan satu paket. Memerlukan } \\
\text { area yang kecil. }\end{array}$ \\
\hline & $\begin{array}{l}\text { Pure Oxygen } \\
\text { Process }\end{array}$ & $85-95$ & $\begin{array}{l}\text { Untuk pengolahan air limbah yang } \\
\text { sulit diuraikan secara bilogis. Luas } \\
\text { area yang dibutuhkan kecil. }\end{array}$ \\
\hline & $\begin{array}{l}\text { Oxidation } \\
\text { Ditch }\end{array}$ & $75-95$ & $\begin{array}{l}\text { Konstruksinya mudah, tetapi } \\
\text { memerlukan area yang luas. }\end{array}$ \\
\hline \multirow{4}{*}{$\begin{array}{l}\text { PROSES } \\
\text { BIOMASA } \\
\text { MELEKAT }\end{array}$} & $\begin{array}{l}\text { Trickling } \\
\text { Filter }\end{array}$ & $80-95$ & $\begin{array}{l}\text { Sering timbul lalat dan bau. Proses } \\
\text { operasinya mudah. }\end{array}$ \\
\hline & $\begin{array}{l}\text { Rotating } \\
\text { Biological } \\
\text { Contactor }\end{array}$ & $80-95$ & $\begin{array}{l}\text { Konsumsi energi rendah, produksi } \\
\text { lumpur kecil. Tidak memerlukan } \\
\text { proses aerasi. }\end{array}$ \\
\hline & $\begin{array}{l}\text { Contact } \\
\text { Aeration } \\
\text { Process }\end{array}$ & $80-95$ & $\begin{array}{l}\text { Memungkinkan untuk penghilangan } \\
\text { nitrogen dan phospor. }\end{array}$ \\
\hline & $\begin{array}{l}\text { Biofilter } \\
\text { Unaerobic }\end{array}$ & $65-85$ & $\begin{array}{l}\text { Memerlukan waktu tinggal yang } \\
\text { lama, lumpur yang terjadi kecil. }\end{array}$ \\
\hline LAGOON & $\begin{array}{l}\text { Kolam } \\
\text { stabilisai }\end{array}$ & $60-80$ & $\begin{array}{l}\text { Memerlukan waktu tinggal yang } \\
\text { cukup lama, dan area yang } \\
\text { dibutukkan sangat luas. }\end{array}$ \\
\hline
\end{tabular}




\section{SUMBER LIMBAH PT NATURA PERISA AROMA}

Sumber air limbah yang ada di PT Natura Perisa Aroma dikelompokan menjadi 2 (dua) kelompok, yaitu limbah domestik dan limbah pabrik atau industri. Air limbah domestik merupakan air limbah yang berasal dari kegiatan tempat ibadah, kamar mandi, toilet, wastafel, kantin, dan air untuk membersihkan lingkungan. Air limbah domestik sendiri dibedakan menjadi dua yaitu grey water dan black water. Grey water adalah air limbah non-toilet seperti air limbah yang dihasilkan dari kegiatan sehari-hari seperti mandi dan mencuci sedangkan untuk air limbah toilet disebut black water.

Air limbah industri merupakan air buangan atau air sisa dari kegiatan industri. Dalam kegiatan industri, air limbah yang dihasilkan berasal dari berbagai sumber sebagai berikut:

a. Proses produksi antara lain :

- Sisa produk pada waktu pembersihan alat/reaktor,

- Tumpahan produk di lingkungan kerja,

- Bekas/sisa bahan pembersih,

- Uap dari bahan baku/produk,

- Bahan yang telah rusak/ kedaluwarsa dan lain-lain.

b. Kegiatan pendukung laboratorium

Setiap kegiatan menghasilkan limbah dengan jumlah dan karakteristik yang berlainan. Meskipun jenis dan besaran kegiatan suatu industri sama, belum tentu jumlah dan karakteristik limbahnya sama. Jumlah dan karakteristik limbah banyak dipengaruhi oleh berbagai faktor, antara lain:

- Teknologi yang digunakan,

- Jenis dan peralatan proses,

- Peralatan /fasilitas kerja yang disediakan,

- Keterampilan dan kemampuan kerja dari SDM,

- Tingkat kesadaran SDM untuk menjaga lingkungan kerja,

- Hubungan kerja antar unit yang ada,

- SOP (Standard Operation Procedure) yang ada.

Dengan mengetahui berbagai faktor sumber timbulan limbah dan faktor-faktor yang mempengaruhinya, diharapkan kita dapat memantau dan menekan seminimal mungkin timbulan limbah yang ada. Dengan meminimalisasikan timbulan limbah dan mengelola limbah sesuai dengan prosedur pengelolaan yang benar didapatkan berbagai keuntungan antara lain:

a. Mengurangi kehilangan bahan baku/produk, b. Meningkatkan efisiensi proses produksi dan kerja,

c. Menghemat biaya pengolahan limbah,

d. Mengurangi resiko kecelakaan kerja,

e. Mengurangi resiko bencana akibat pencemaran limbah,

f. Menghindarkan konflik sosial dengan lingkungan sekitar akibat limbah,

g. Meningkatkan persepsi positif di mata konsumen, karena telah melakukan proses produksi bersih.

h. Meningkatkan nilai jual dan daya saing produk.

Menekan jumlah timbulan limbah berarti juga meningkatkan efisiensi biaya proses produksi, hal ini dapat dilakukan dengan berbagai upaya antara lain:

a. Memperbaiki teknologi proses,

b. Mengoptimalkan kondisi operasi proses,

c. Mengurangi kehilangan produk,

d. Memperbaiki SOP proses produksi.

e. Meningkatan keahlian SDM yang ada.

Unit produksi minyak atsiri PT Natura Perisa Aroma Lampung direncanakan memproduksi minyak atsiri dari 5 (lima) bahan baku utama yaitu pala (nutmeg), lada hitam (black pepper), kayu manis (cassia), cengkeh (clove) dan sereh wangi (citronela). Masing-masing proses produksi dirancang menggunakan unit proses produksi yang berbeda dan kapasitas yang tidak sama. Meskipun demikian, sumber air limbah yang dihasilkan dari semua proses produksi bersumber dari unit oil separator dan air limbah yang berasal dari laboratorium pengendalian mutu serta pencucian unit peralatan.

\section{KARAKTERISTIK AIR LIMBAH PT NATURA PERISA AROMA}

Masing-masing limbah yang sumbernya berlainan tersebut mempunyai karakteristik yang berbeda, tetapi pada dasarnya dapat digolongkan dalam dua kelompok, yaitu limbah yang mengandung bahan kimia (dari proses produksi) dan yang tidak mengandung bahan kimia dari toilet dan kantin (non-kimia). Dilihat dari sifat bahan polutan yang ada limbah non-kimia merupakan limbah yang mudah untuk didegradasi dan jika dilakukan pengelolaan dengan baik tidak menimbulkan banyak permasalahan. Sedangkan limbah kimia merupakan limbah yang relatif lebih sulit untuk didegradasi. Limbah ini sering menimbulkan dampak lingkungan yang berkelanjutan seperti, bau/aroma, kerusakan biota dan struktur tanah, bertahan dalam jangka waktu yang lama dan sebagian lagi dapat menimbulkan bahaya keracunan dll.

Berdasarkan perkiraan karakteristik air limbahnya, maka teknologi pengolahan air limbah 
produksi yang tepat untuk PT Natura Perisa Aroma adalah kombinasi antara proses kimiafisika dengan proses biologi. Proses kimia-fisika digunakan untuk mengikat polutan-polutan organik yang sukar didegradasi dan polutan yang tidak terlarut, sedangkan proses biologi untuk mendegradasi polutan-polutan organik terlarut serta polutan lain yang tidak terolah pada proses kimia-fisika.

Pada proses kimia-fisika, akan ditambahkan bahan-bahan kimia untuk menetralkan $\mathrm{pH}$, bila air limbah yang dihasilkan bersifat asam maka air limbah tersebut ditambahkan larutan $\mathrm{CaO}$ atau $\mathrm{Ca}(\mathrm{OH})_{2}$, dan bila larutan hasil produksi bersifat basa, maka ke dalam air limbah ditambahkan larutan $\mathrm{H}_{2} \mathrm{SO}_{4}$ atau $\mathrm{HCl}$. Dengan penyesuaian $\mathrm{pH}$ pada air limbah ini diharapkan pertumbuhan bakteri di reaktor lumpur aktif meningkat sehingga proses degradasi polutan menjadi lebih cepat. Pengolahan biologi yang akan diaplikasikan untuk mengolah air olahan proses kimia-fisika adalah proses biologi dengan menggunakan teknologi lumpur aktif.

PT Natura Perisa Aroma membangun plant baru yang memproduksi minyak atsiri dari beberapa bahan baku seperti cengkeh (clove), pala (nutmeg), kayu manis (cassia), sereh wangi (citronella) dan lada hitam (black pepper). Di dalam proses produksi minyak atsiri dengan bahan baku berbeda memiliki tahapan proses produksi yang berbeda, namun pada dasarnya, sumber air limbah yang dihasilkan dari proses separator minyak atsiri sehingga kondisi air limbah segar yang dihasilkan memiliki temperatur yang cukup tinggi. Kondisi ini dapat menyebakan menurunkan kinerja IPAL karena pengolahan air limbah menggunakan proses biologi yang menggunakan mikroorganisme. Perencanaan IPAL ini membutuhkan unit pretreatment dari air limbah segar sebelum masuk ke dalam sistem IPAL PT Natura Perisa Aroma. Karakteristik air limbah produksi minyak atsiri PT Natura Perisa Aroma dapat dilihat pada Tabel 3.

Tabel 3. Hasil Pengujian Air Limbah Segar PT Natura Perisa Aroma

\begin{tabular}{l|c|c}
\hline \multicolumn{1}{c|}{ Parameter } & Satuan & Inlet \\
\hline Temperatur & ${ }^{\circ} \mathrm{C}$ & 62 \\
\hline Zat Padat Terlarut & $\mathrm{mg} / \mathrm{L}$ & 57 \\
\hline Zat Padat Suspensi & $\mathrm{mg} / \mathrm{L}$ & 68 \\
\hline $\mathrm{pH}$ & - & 4 \\
\hline Besi Terlarut (Fe) & $\mathrm{mg} / \mathrm{L}$ & 0,1 \\
\hline Mangan Terlarut (Mn) & $\mathrm{mg} / \mathrm{L}$ & $<0,003$ \\
\hline Cadmium (Cd) & $\mathrm{mg} / \mathrm{L}$ & $<0,002$ \\
\hline Air Raksa $(\mathrm{Hg})$ & $\mathrm{mg} / \mathrm{L}$ & $<0.0005$ \\
\hline Timbal $(\mathrm{Pb})$ & $\mathrm{mg} / \mathrm{L}$ & $<0,004$ \\
\hline Arsen $(\mathrm{As})$ & $\mathrm{mg} / \mathrm{L}$ & $<0,005$ \\
\hline Selenium (Se) & $\mathrm{mg} / \mathrm{L}$ & $<0.002$ \\
\hline Amonia-Nitrogen & $\mathrm{mg} / \mathrm{L}$ & 0,3 \\
\hline BOD & $\mathrm{mg} / \mathrm{L}$ & 107 \\
\hline
\end{tabular}

\begin{tabular}{l|c|c}
\hline \multicolumn{1}{c|}{ Parameter } & Satuan & Inlet \\
\hline COD & $\mathrm{mg} / \mathrm{L}$ & 714 \\
\hline $\begin{array}{l}\text { Senyawa Aktif Biru } \\
\text { Metilen }\end{array}$ & $\mathrm{mg} / \mathrm{L}$ & 0,04 \\
\hline Fenol & $\mathrm{mg} / \mathrm{L}$ & 3 \\
\hline Minyak dan Lemak & $\mathrm{mg} / \mathrm{L}$ & 2 \\
\hline $\begin{array}{l}\text { Sumber : Laporan Hasil Pengujian Inlet PT Natura } \\
\text { Perisa Aroma - UNILAB }\end{array}$
\end{tabular}

\section{DESAIN INSTALASI PENGOLAHAN LIMBAH INDUSTRI PT NATURA PERISA AROMA}

\subsection{Penentuan Kapasitas dan Desain Proses IPAL PT Natura Perisa Aroma Lampung}

Sebelum adanya perancangan Instalasi Pengolahan Air Limbah PT Natura Perisa Aroma perlu dilakukan penghitungan kapasitas desain IPAL dengan menghitung jumlah air limbah yang dihasilkan dari proses produksi dan kegiatan pendukung lainnya. Jumlah air limbah yang dihasilkan dari setiap proses sebagai berikut:

Tabel 4. Jumlah Total Air Limbah Yang Dihasilkan PT Natura Perisa Aroma

\begin{tabular}{l|c}
\hline \multicolumn{1}{c|}{ Sumber Limbah } & $\begin{array}{c}\text { Jumalah limbah } \\
\left(\mathbf{m}^{\mathbf{3}} \mathbf{h} \mathbf{h} \mathbf{a r}\right)\end{array}$ \\
\hline Proses Nutmeg & 2 \\
\hline Proses Black pepper & 2 \\
\hline Proses Cassia & 5 \\
\hline Proses Clove & 2 \\
\hline Proses Citronella & 2 \\
\hline Laboratorium & 1 \\
\hline $\begin{array}{l}\text { Sistem pencucian } \\
\text { peralatan }\end{array}$ & 4 \\
\hline Total & $\mathbf{1 8}$ \\
\hline
\end{tabular}

Sumber : Data PT Natura Perisa Aroma 2017

Dengan adanya data jumlah air limbah yang dihasilkan di unit produksi minyak atsiri PT Natura Perisa Aroma (Tabel 4), maka kapasitas IPAL yang direncanakan adalah sebesar 20 $\mathrm{m}^{3}$ /hari. Perencanaan IPAL Unit Minyak Atsiri PT Natura Perisa Aroma ini tentunya juga memperhatikan karakteristik air limbah diantaranya suhu air limbah yang dihasilkan masih cukup tinggi. Perancangan unit IPAL PT Natura Perisa Aroma unit minyak atsiri direncanakan perlu adanya unit pretreatment untuk menurunkan suhu air limbah sebelum masuk ke dalam proses sistem IPAL. Unit pretreatment ini yaitu sistem pendinginan sederhana menggunakan bak penampung terbuka dengan luas permukaan yang cukup. Air limbah yang dihasilkan akan ditampung dalam bak penampung ini dan pada ketinggian tertentu diumpankan masuk ke dalam sistem IPAL. Sistem pengumpanan seperti ini dapat dilakukan karena air limbah yang dihasilkan tidak bersifat kontinyu. 
Air limbah yang dihasilkan mengikuti proses produksi yang bersifat batch dengan lama waktu proses $8-12$ jam.

Perancangan unit sistem IPAL PT Natura Perisa Aroma pada dasarnya memiliki teknologi IPAL industri seperti pada umumnya. Air limbah yang akan diolah dari unit pretreatment masuk ke dalam bak sedimentasi pertama untuk proses pengendapan dan selanjutnya masuk ke dalam bak oil trap. Pada bak oil trap ini proses pemisahan sisa minyak atsiri terjadi. Air limbah dari oil trap selanjutnya masuk ke dalam unit ekualisasi. Pada unit ekualisasi terdapat proses netralisasi yaitu proses penetralan $\mathrm{pH}$. Air limbah dari ekualisasi akan diproses ke dalam bak lumpur aktif. Di dalam bak lumpur aktif terdapat proses biologis, yaitu proses penguraian zat-zat organik oleh mikroba. Hasil pengolahan air limbah dari lumpur aktif selanjutnya masuk ke dalam bak sedimentasi kedua untuk proses pengendapan. Proses sedimentasi ini berfungsi untuk mengembalikan lumpur aktif yang terikut dan direcycle ke dalam bak lumpur aktif dan sebagian dilakukan penanganan sebagai limbah B3 padat. Penanganan limbah padat ini terjadi di unit pengeringan lumpur. Air limbah dari unit sedimentasi selanjutnya menjadi outlet hasil IPAL. Secara keseluruhan diagram alir proses IPAL dapat dilihat pada Gambar 6 dan 7.

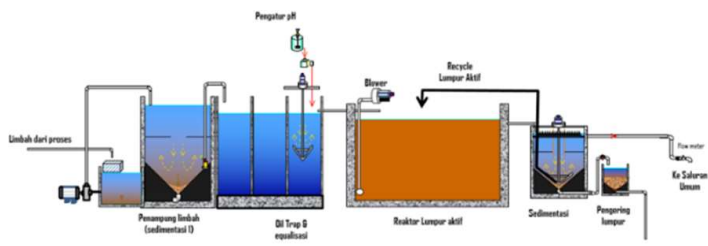

Gambar 6. Diagram Alir Proses IPAL PT Natura Perisa Aroma

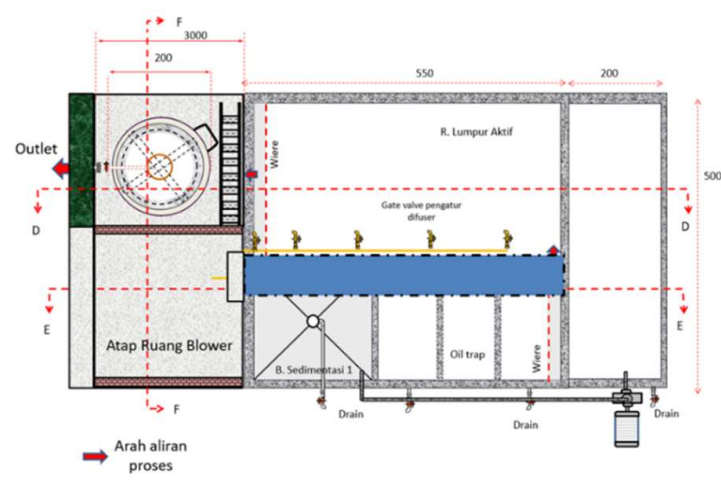

Gambar 7. Layout IPAL PT Natura Perisa Aroma Lampung.

\subsection{Tahapan dan Spesifikasi Teknis Peralatan IPAL PT Natura Perisa Aroma Lampung}

a. Bak Penampung Air Limbah
Bak penampung air limbah merupakan unit yang berfungsi sebagai unit pretreatment suhu air limbah sebelum masuk ke dalam proses IPAL. Treatment yang terjadi di bak penampung ini adalah proses penurunan suhu air limbah. Air limbah yang dihasilkan dari proses produksi memiliki suhu antara $50^{\circ} \mathrm{C}-65^{\circ} \mathrm{C}$. Bak penampung direncanakan dapat menampung 10 $\mathrm{m}^{3}$ dalam sekali proses penurunan suhu.

Ukuran dan dimensi bak penampung sebagai berikut :

Tabel 4. Spesifikasi Bak Penampung Air Limbah

\begin{tabular}{l|c|c}
\hline \multicolumn{1}{c|}{ Spesifikasi } & Satuan & Keterangan \\
\hline Panjang & $\mathrm{m}$ & 5 \\
\hline Lebar & $\mathrm{m}$ & 2 \\
\hline Tinggi & $\mathrm{m}$ & 1 \\
\hline Kapasitas & $\mathrm{m}^{3}$ & 10 \\
\hline Material & - & Beton bertulang
\end{tabular}

b. Bak Sedimentasi 1

Bak pengendap yang direncanakan adalah tipe gravitasi, berbentuk persegi dengan bagian bawah berbentuk kerucut. Fungsi dari bak ini adalah untuk memisahkan lumpur/padatan dari proses dan pembersihan peralatan produksi. Bak ini dilengkapi dengan pompa transfer untuk memompa limbah ke bak ekualisasi, dan dilengkapi pula dengan sistem level control dengan bak ekualisasi, sehingga jika kondisi bak ekualisasi sudah penuh akan mematikan pompa secara otomatis. Dengan sistem ini, tidak akan terjadi tumpahan limbah di bak ekualisasi. Adapun dimensi bak sedimentasi adalah sebagai berikut :

Tabel 5. Spesifikasi Bak Penampung

\begin{tabular}{l|c|c}
\hline \multicolumn{1}{c|}{ Spesifikasi } & Satuan & Keterangan \\
\hline Panjang & $\mathrm{m}$ & 2 \\
\hline Lebar & $\mathrm{m}$ & 2 \\
\hline Tinggi & $\mathrm{m}$ & 3 \\
\hline Kapasitas & $\mathrm{m}^{3}$ & 12 \\
\hline Material & - & Beton bertulang \\
\hline
\end{tabular}

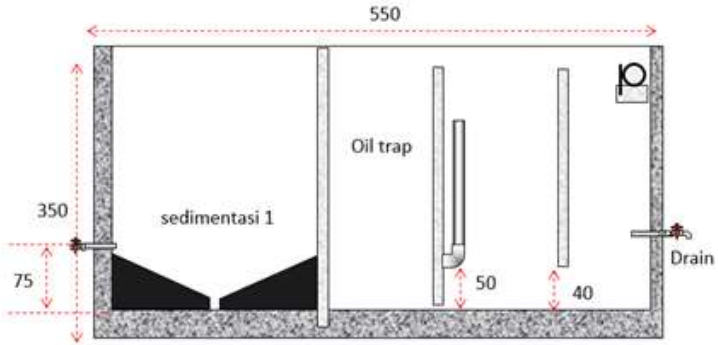

Gambar 8. Potongan bak sedimentasi 1 dan oil trap

\section{c. Bak Oil Trap}

Tujuan dari pemisahan minyak adalah untuk menghilangkan minyak dan senyawa hidrokarbon lainnya di dalam proses emulsi mekanik, karena kandungan minyak ini dapat 
mengganggu proses pengolahan air limbah dalam biofilter. Air yang dihasilkan harus bebas minyak sehingga proses biofilter dapat berjalan dengan sempurna efektif dan efisien. Pemisahan minyak dilakukan tanpa adanya penambahan bahan kimia, tetapi hanya dilakukan dengan cara gravitasi alami, dimana cairan minyak naik dengan kecepatan ke atas yang ada dibatasi oleh berat jenisnya (specific gravity).

Dalam perancangan bak oil trap ini digunakan oil trap jenis gravity separator. Separator ini menggunakan prinsip pemisahan yang memanfaatkan beda berat jenis minyak dan air. Minyak yang memiliki densitas lebih rendah akan mengambang dan membentuk lapisan tipis di atas permukaan air.

Tabel 6. Spesifikasi Bak Oil Trap

\begin{tabular}{l|c|c}
\hline \multicolumn{1}{c|}{ Spesifikasi } & Satuan & Keterangan \\
\hline Panjang & $\mathrm{m}$ & 3.5 \\
\hline Lebar & $\mathrm{m}$ & 2 \\
\hline Tinggi & $\mathrm{m}$ & 3 \\
\hline Tipe & & Gravity separator \\
\hline Kapasitas & $\mathrm{m}^{3}$ & 21 \\
\hline Material & - & Beton bertulang \\
\hline
\end{tabular}

d. Unit Netralisasi

Unit netralisasi terdiri dari tangki bahan kimia dan unit pompa dosing. Pada unit netralisasi terjadi proses pengontrolan $\mathrm{pH}$ air limbah sebelum masuk ke proses biologi di kolam lumpur aktif. Air limbah yang dihasilkan oleh PT Natura Perisa Aroma Lampung bersifat asam sehingga perlu dinaikkan $\mathrm{pH}$-nya menggunakan cairan larutan basa Natrium Hidroksida $(\mathrm{NaOH})$. Spesifikasi unit netralisasi sebagai berikut :

Tabel 7. Spesifikasi Unit Netralisasi IPAL PT Natura Perisa Aroma

\begin{tabular}{l|c|c}
\hline \multicolumn{1}{c|}{ Spesifikasi } & Satuan & Keterangan \\
\hline V Tangki & liter & 300 \\
\hline Bahan tangki & & $\begin{array}{c}\text { Melt Compounded } \\
\text { Polyethylen }\end{array}$ \\
\hline Tipe & $\mathrm{m}$ & TB32 \\
\hline Tinggi tangki & $\mathrm{m}$ & 0.67 \\
\hline $\begin{array}{l}\text { Diameter } \\
\text { tangki }\end{array}$ & - & 0.69 \\
\hline Tipe Pompa & Dosing Pump \\
\hline Debit & Liter/jam & 14.7 \\
\hline
\end{tabular}

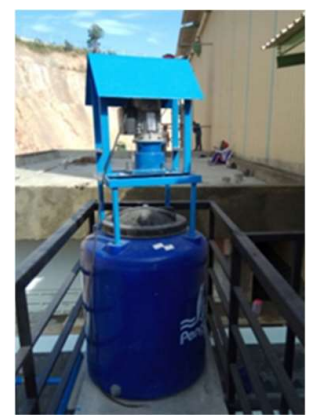

Gambar 9. Unit Netralisasi e. Unit Reaktor Lumpur Aktif

Proses lumpur aktif termasuk proses biologis aerobik, yaitu proses penguraian polutan organik dalam air limbah dengan menggunakan mikroorganisme dan oksigen menjadi $\mathrm{CO}_{2}$ dan $\mathrm{H}_{2} \mathrm{O}, \mathrm{NH}_{4}$ dan sel biomassa baru. Perlengkapan atau peralatan standar yang digunakan dalam proses lumpur aktif meliputi:

- Tangki aerasi tempat bereaksinya air limbah dengan mikro-organisme pengurai air limbah. Mikro-organisme tersuspensi yang ada dalam air limbah dinamakan activated sludge.

- Bak pengendap untuk memisahkan air limbah yang telah dimurnikan dari lumpur mikro-organisme.

- Sistem sirkulasi untuk membalikkan sebagian lumpur dari bak pengendap ke tangki aerasi. Sirkulasi ini digunakan untuk menjaga konsentrasi mikro-organisme dalam tangki aerasi. Tinggi rendahnya konsentrasi mikro-organisme dalam tangki aerasi merupakan salah satu faktor yang mempengaruhi efisiensi pengolahan.

- Sistem pengolahan dan pembuangan kelebihan lumpur sebagai akibat dari pertumbuhan mikro-organisme.

- Peralatan pemasok udara seperti blower dan difuser udara.

- Sistem pengadukan seperti untuk membuat campuran mikro-organisme dan air limbah homogen serta tidak mencegah pengendapan lumpur dalam tangki aerasi. Sistem ini tidak perlu digunakan apabila distribusi udara dalam kolam aerasi sudah cukup besar dan tidak terjadi pengendapan. Udara disalurkan melalui pompa blower (diffused) atau melalui aerasi mekanik. Sel mikroba membentuk flok yang akan mengendap di tangki pengendap.

Tabel 8: Spesifikasi Bak Lumpur Aktif

\begin{tabular}{l|c|c}
\hline \multicolumn{1}{c|}{ Spesifikasi } & Satuan & Keterangan \\
\hline Panjang & $\mathrm{m}$ & 5.5 \\
\hline Lebar & $\mathrm{m}$ & 2 \\
\hline Tinggi & $\mathrm{m}$ & 4.5 \\
\hline Vol. Efektif & $\mathrm{m}^{3}$ & 47 \\
\hline Material & - & Beton bertulang \\
\hline
\end{tabular}

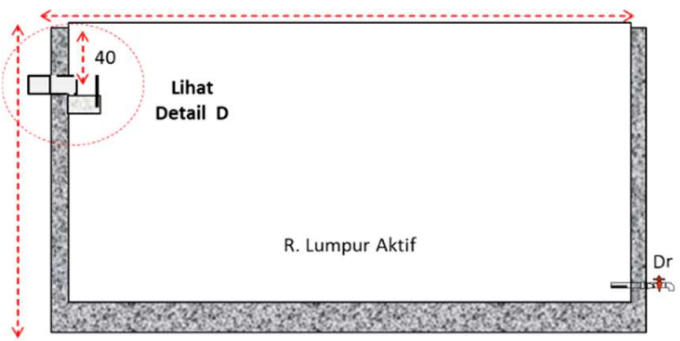

Gambar 10. Bak Lumpur Aktif 


\section{f. Blower dan Fine Buble Diffuser}

Difuser menggunakan tipe fine buble diffuser dan/ atau coarse bubble diffuser. Difuser ini secara teknis lebih efisien dibanding dengan tipe perforated, sehingga akan meningkatkan jumlah difusi oksigen ke dalam air limbah sehingga akan menjadikan kondisi mikroba akan lebih aktif serta mempercepat proses degradasi polutan yang ada.
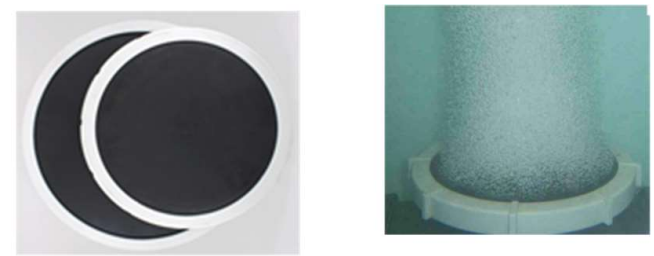

Gambar 11. Difuser tipe fine bubble

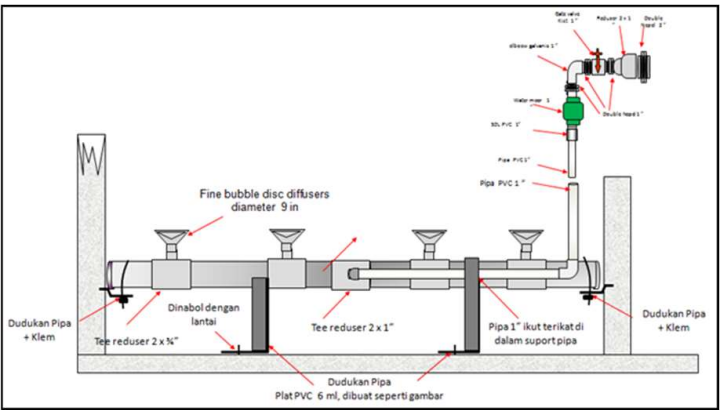

Gambar 12. Desain Pemasangan Difuser

Spesifikasi teknis difuser udara sebagai berikut:

- Type

: Fine bubble diffusers

- Standard

: 9" Disc - AFD270

- Design Flow: 1.5-3.0 SCFM $\mathrm{Nm}^{3} / \mathrm{hr}$ )

$(2.5-5.0$

- Flow Range : 0-7 SCFM (0-12 Nm³/hr)

- SOT : efficiencies of up to $3.3 \% / \mathrm{ft}$ $(11 \% / m)$

g. Bak Sedimentasi 2

Sedimentasi adalah suatu unit operasi untuk menghilangkan materi tersuspensi atau flok kimia secara gravitasi. Proses sedimentasi pada pengolahan air limbah umumnya untuk menghilangkan padatan tersuspensi sebelum dilakukan proses pengolahan selanjutnya. Gumpalan padatan yang terbentuk pada proses koagulasi masih berukuran kecil. Gumpalangumpalan kecil ini akan terus saling bergabung menjadi gumpalan yang lebih besar dalam proses flokulasi. Dengan terbentuknya gumpalangumpalan besar, maka beratnya akan bertambah, sehingga karena gaya beratnya gumpalangumpalan tersebut akan bergerak ke bawah dan mengendap pada bagian dasar tangki sedimentasi.

Bak sedimentasi dapat berbentuk segi empat atau lingkaran. Pada bak ini aliran air limbah dibuat sangat tenang untuk memberi kesempatan padatan/suspensi untuk mengendap. Kriteria-kriteria yang diperlukan untuk menentukan ukuran bak sedimentasi adalah: surface loading (beban permukaan), kedalaman bak dan waktu tinggal. Waktu tinggal mempunyai satuan jam, cara perhitungannya adalah volume tangki dibagi dengan laju alir per hari. Beban permukaan sama dengan laju alir (debit volume) rata-rata per hari dibagi luas permukaan bak, satuannya meter kubik per meter persegi per hari.

$$
V_{0}=\frac{Q}{A}
$$

Keterangan:

Vo = laju limpahan/beban permukaan $\left(\mathrm{m}^{3} / \mathrm{m}^{2}\right.$ day)

$\mathrm{Q} \quad=$ aliran rata-rata harian, $\mathrm{m}^{3}$ per hari

A $=$ total luas permukaan $\left(\mathrm{m}^{2}\right)$

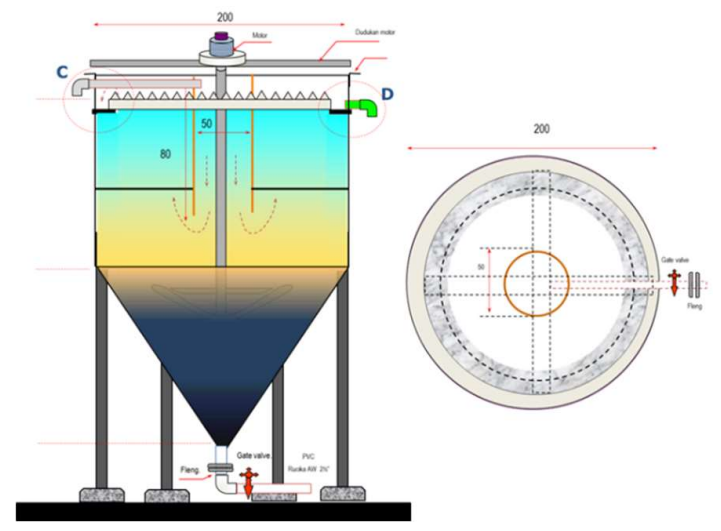

Gambar 13. Desain Bak Sedimentasi 2

Spesifikasi teknis bak sedimentasi 2 dapat dilihat pada tabel 9 .

Tabel 9. Spesifikasi Bak Sedimentasi 2

\begin{tabular}{|c|c|c|}
\hline Spesifikasi & $\begin{array}{c}\text { Satua } \\
\text { n }\end{array}$ & Keterangan \\
\hline Diameter & $\mathrm{m}$ & 2 \\
\hline T efektif & $\mathrm{m}$ & 2.3 \\
\hline V efektif & $\mathrm{m}^{3}$ & 4.8 \\
\hline $\begin{array}{l}\text { Waktu } \\
\text { Tinggal }\end{array}$ & menit & 173 \\
\hline Kapasitas & $\mathrm{m}^{3} /$ hari & 4.9 \\
\hline Material & & Fiber \\
\hline
\end{tabular}

h. Bak Pengering Lumpur

Lumpur yang dihasilkan dari proses sedimentasi di tangki sedimentasi sebagian di pompa kembali ke kolam lumpur aktif dan sebagian lagi dimasukan ke dalam bak pengering lumpur untuk dilakukan pengeringan. 


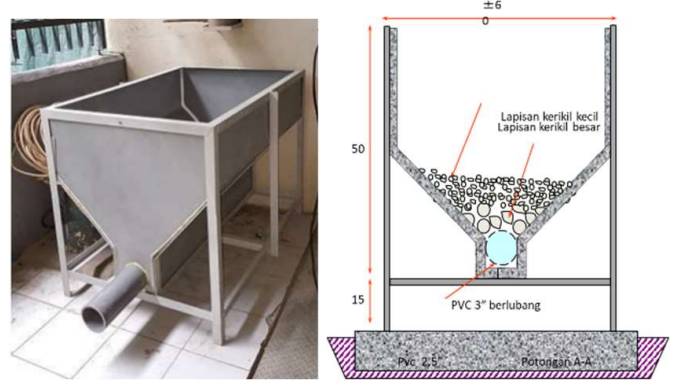

Gambar 14. Desain Bak Pengering Lumpur

Proses pengeringan lumpur dilakukan secara alami yaitu dikeringkan dengan menggunakan sinar matahari. Lumpur yang kering selanjutnya di masukan kedalam karung untuk dilakukan pengolahan lebih lanjut.

Tabel 10: Spesifikasi Bak Pengering Lumpur

\begin{tabular}{l|c|c}
\hline \multicolumn{1}{c}{ Spesifikasi } & Satuan & Keterangan \\
\hline Panjang & $\mathrm{cm}$ & 100 \\
\hline Lebar & $\mathrm{cm}$ & 60 \\
\hline Tinggi & $\mathrm{cm}$ & 65 \\
\hline Material & & PVC - kerangka galvanis \\
\hline
\end{tabular}

i. Unit Sistem Kelistrikan

Untuk sistem penyediaan listrik masingmasing peralatan IPAL PT Natura Perisa Aroma dapat dilihat dalam tabel 9 sebagai berikut:

Tabel 11. Kebutuhan listrik IPAL PT Natura

\begin{tabular}{l|c|c}
\multicolumn{3}{|c}{ Perisa Aroma } \\
\hline \multicolumn{1}{c}{ Peralatan } & Satuan & Keterangan \\
\hline Pompa 1 phase & $\mathrm{kW}$ & 1.5 \\
\hline $\begin{array}{l}\text { Dosing Pump } \\
\text { dan Agitator } \\
\text { Kimia }\end{array}$ & $\mathrm{kW}$ & 0.75 \\
\hline Agitator 1 & $\mathrm{kW}$ & 1.0 \\
\hline Agitator 2 & $\mathrm{kW}$ & 1.0 \\
\hline Pompa Recycle & $\mathrm{kW}$ & 1.0 \\
\hline Blower 1 & $\mathrm{kW}$ & 6.0 \\
\hline Blower 2 & $\mathrm{kW}$ & 6.0 \\
\hline Spare & $\mathrm{kW}$ & 17.25 \\
\hline Total & & \\
\hline
\end{tabular}

\begin{tabular}{|ll|}
\hline Daftar kebjtuhan power: & $=1,5 \mathrm{~kW}, 1$ Phase \\
1. Pompa 1 phase, & $=0,75 \mathrm{~kW}, 1$ Phase \\
2. Dosing 1 buah + agitator 1 buah, total & $=1,0 \mathrm{~kW}, 1$ Phase \\
3. Agitator & $=1,0 \mathrm{~kW}, 1$ Phase \\
4. Agitator & $=1,0 \mathrm{~kW}, 1$ Phase \\
5. Pompa recycle & $=6 \mathrm{~kW}, 3$ Phase \\
6. Blower & $=6 \mathrm{~kW}, 3$ Phase \\
7. Blower & \\
8. Spare lampu saja. & \\
Blower (6 \& 7) hidup bergantian dengan pengaturan menggunakan \\
timer.
\end{tabular}

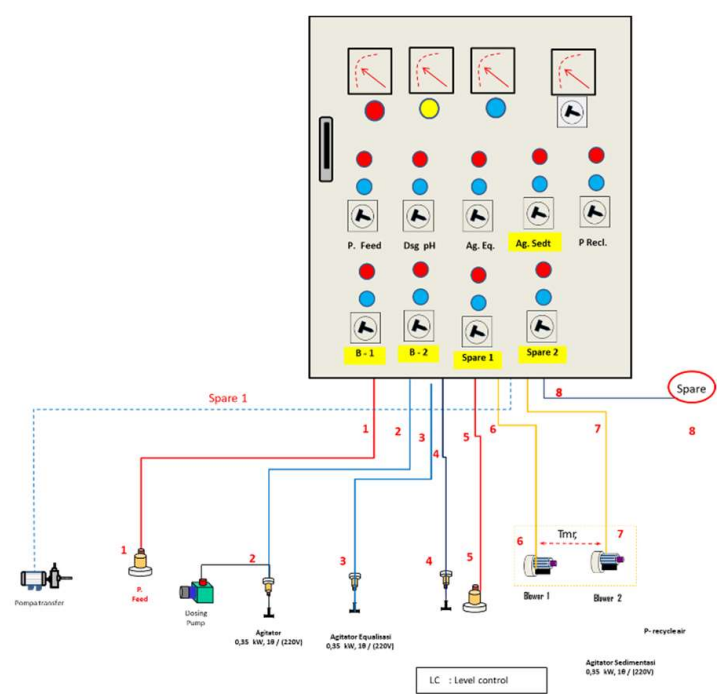

Gambar 15. Panel Kontrol IPAL

\section{START-UP DAN MONITORING HASIL PENGOLAHAN AIR LIMBAH}

\subsection{Start-Up IPAL PT Natura Perisa Aroma.}

Pekerjaan start-up WWTP (IPAL) merupakan pekerjaan pengoperasian awal IPAL yang meliputi penyiapan nutrisi, penyiapan bakteri pendegradasi polutan, seeding bakteri dan pemberian nutrisi ke dalam instalasi Pengolahan Air Limbah PT. Natura Perisa Aroma, serta pengoperasian pompa-pompa sehingga IPAL dapat beroperasi dengan baik.

Tahapan-tahapan dalam proses start-up adalah sebagai berikut :

a. Proses pengecekan unit IPAL dan kelengkapannya.

Sebelum melakukan start-up dilakukan pengecekkan ulang terhadap semua pekerjaan yang meliputi :

- Pengecekan fisik bangunan WWTP

- Pengecekan sistem perpipaan jaringan air limbah,

- Pengecekan sistem perpipaan jaringan udara

- Pengecekan sistem kelistrikan beserta panel listrik

- Pengecekan peralatan dan mesin,

- Pengecekan sistem WWTP itu sendiri. 


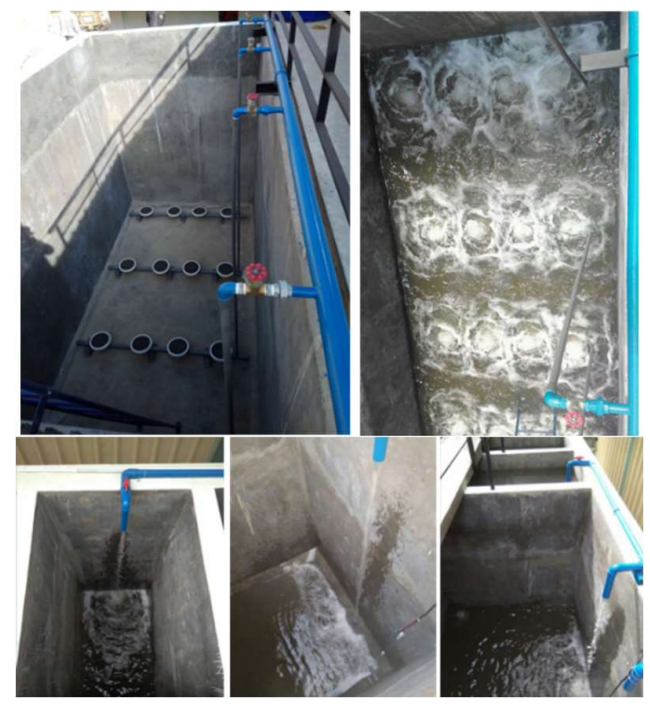

Gambar 16. Pengecekan fisik bangunan WWTP

b. Proses persiapan bahan penjerap pengering lumpur

Proses selanjutnya adalah dengan menyiapkan bahan penjerap lumpur di bak pengering lumpur. Bahan penjerap terdiri atas batu, kerikil dan pasir. Gambar 17 memperlihatkan bahan penjerap lumpur di bak pengering.

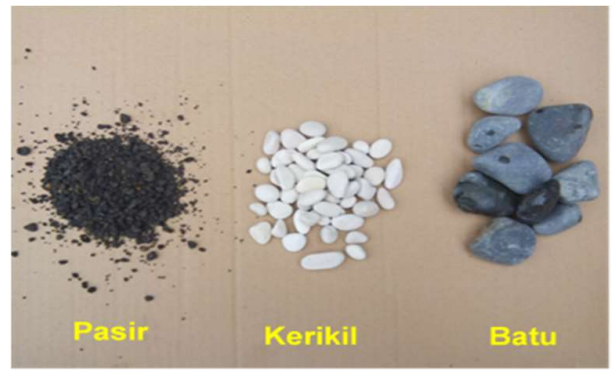

Gambar 17. Bahan Penjerap lumpur di Bak Pengering Lumpur

Pemasangan bahan penjerap ini dimulai dengan peletakan batu hitam di dasar bak pengering lumpur. Setelah batu kecil sudah tersebar merata di atas bak pengering lumpur selanjutnya di atas permukaan batu hitam tersebut diletakkan batu kerikil warna putih. Batu kerikil ini disusun dan permukaannya dirapihkan sehingga permukaannya menjadi rata, di atas permukaan ini diberi lapisan pasir lalu ditutup dengan lapisan penyaring yang berfungsi untuk menyaring endapan. Pemasangan penjerap lumpur disajikan secara rinci pada Gambar 18 di bawah ini.
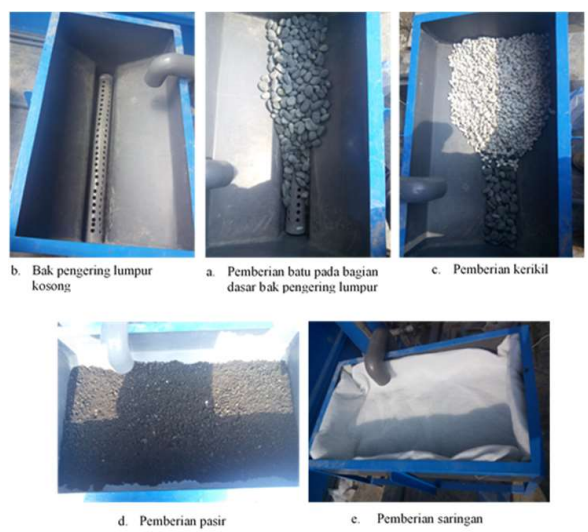

Gambar 18. Pemasangan penjerap lumpur di bak pengering lumpur

c. Proses persiapan dan pemberian nutrisi IPAL

Pemberian bakteri ke dalam Instalasi Pengolahan Air Limbah (IPAL) penting dilakukan karena bakteri merupakan salah satu agensia pendegradasi dalam mereduksi jumlah polutan di dalam air limbah. Senyawa organik yang ada dengan bantuan oksigen akan dimanfaatkan bakteri sebagai sumber energinya dalam melakukan metabolismenya. Dalam hal ini senyawa organik bermolekul besar seperti lemak, lipid dan senyawa komplek lainnya akan diurai menjadi senyawa yang lebih sederhana seperti gas $\mathrm{CO}_{2}$.

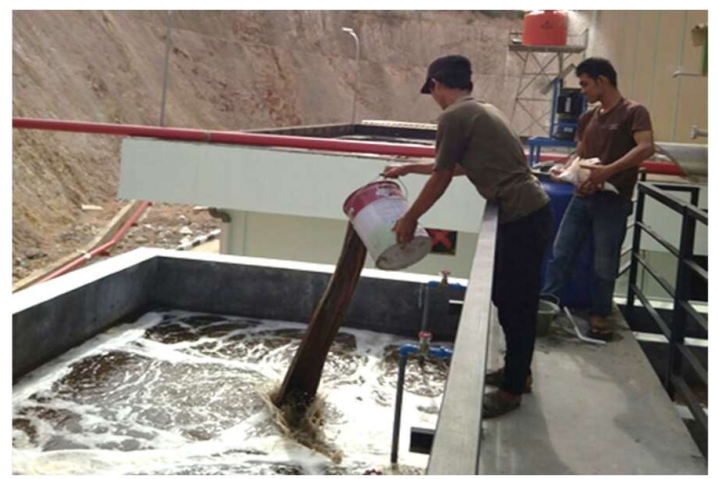

Gambar 19. Pemberian bibit \& nutrisi mikroba sebagai upaya untuk menumbuhkan mikroba secara langsung dari sumber limbah

\subsection{Monitoring IPAL PT Natura Perisa Aroma.}

Pada pekerjaan ini dilakukan pengamatan secara visual yaitu dengan mengambil contoh air limbah di bak pengumpul, bak oil trap, reaktor lumpur aktif, lumpur recycle, dan bak sedimen untuk dimasukan ke dalam gelas beker, lalu didiamkan selama 15 menit. Setelah itu dilakukan pengamatan secara visual (Gambar 20). 


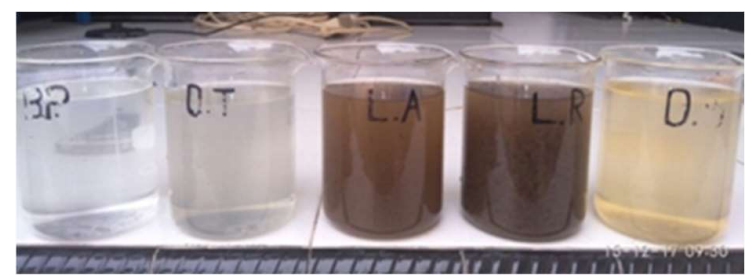

Gambar 20. Sampel hasil pengolahan IPAL PT Natura Perisa Aroma (0 menit)

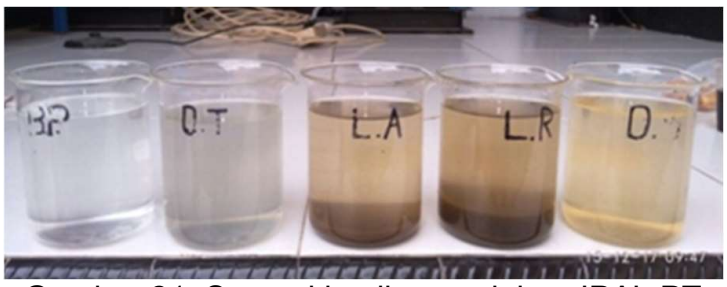

Gambar 21. Sampel hasil pengolahan IPAL PT Natura Perisa Aroma (15 menit)

Keterangan :

(BP = bak pengumpul, OT = oil trap, LA = lumpur aktif, $\mathrm{LS}=$ lumpur recycle, $\mathrm{OS}=$ outlet sedimentasi)

Selain pengukuran secara visual, dilakukan juga pengambilan contoh air limbah di bak pengumpul, reaktor lumpur aktif dan outlet bak sedimentasi. Contoh air limbah yang telah dikumpulkan tersebut selanjutnya di bawah ke laboratorium untuk dilakukan analisa laboratorium. Gambar 22., menyajikan proses pengambilan contoh air limbah di WWTP PT. Natura Perisa Aroma.

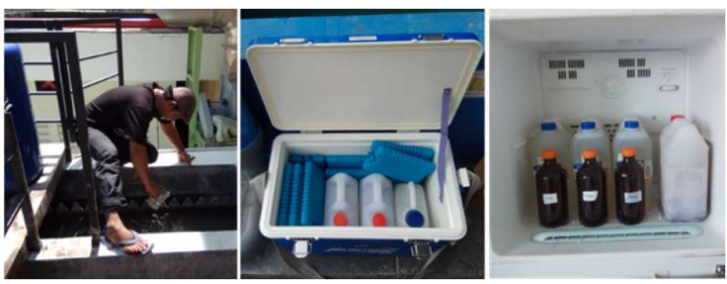

Gambar 22. Proses pengambilan contoh air limbah di WWTP PT. Natura Perisa Aroma

Kegiatan monitoring dilaksanakan dengan melakukan pengambilan sampel di lima titik yaitu di bak penampung (BP), oil trap (OT), bak lumpur aktif (LA), bak lumpur recycle (LR), outlet sedimentasi (OS) dan selanjutnya diukur $\mathrm{pH}$ masing-masing sampel. Hasil pengukuran $\mathrm{pH}$ masing-masing sampel tersebut dapat dilihat dari grafik pH dalam waktu dua bulan monitoring dapat ditunjukkan pada gambar 23 dan gambar 24 .

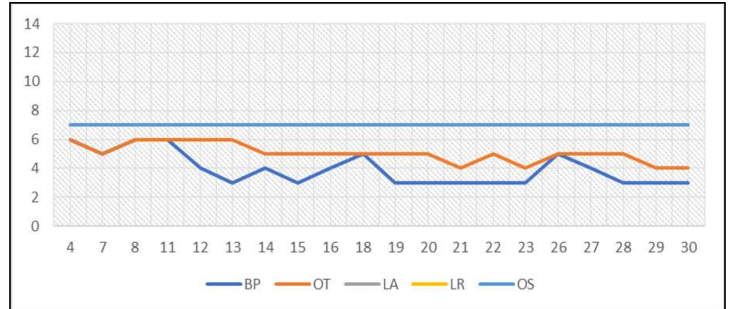

Gambar 23. Grafik pengukuran pH sampel IPAL PT Natura Perisa Aroma Bulan Desember 2017

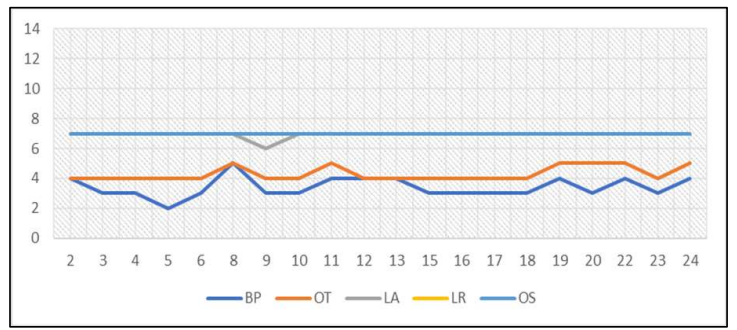

Gambar 24. Grafik pengukuran pH sampel IPAL PT Natura Perisa Aroma Bulan Januari 2018

Sampel BP merupakan sampel yang diambil dari bak penampung yang merupakan limbah segar dihasilkan dari proses produksi dan pencucian alat produksi Hasil pengambilan sampel dan pengukuran $\mathrm{pH}$ didapatkan bahwa $\mathrm{pH}$ sampel BP cukup rendah (asam) hal ini dapat disebabkan oleh air limbah yang dihasilkan bersifat asam. Pengolahan air limbah dengan proses lumpur aktif pada IPAL PT Natura Perisa Aroma terdiri dari bak pengumpul, bak pengendap awal (ekualisasi), bak aerasi lumpur aktif dan bak pengendap akhir. Pada pengambilan sampel di oil trap (OT) terdapat proses netralisasi air limbah, dimana pada proses ini terdapat proses kenaikan $\mathrm{pH}$. Proses netralisasi ini menggunakan bahan kimia kaustik soda $(\mathrm{NaOH})$. Proses selanjutnya air limbah dialirkan ke proses lumpur aktif dilengkapi dengan proses aerasi. Pada prses ini diambil sampel pengecekkan $\mathrm{pH}$ (LA). $\mathrm{pH}$ sampel di lumpur aktif mengalami peningkatan dan lebih stabil. Proses pengambilan sampel selanjutnya dilakukan pada lumpur recycle dan keluaran bak sedimentasi. Pada kedua tahap ini $\mathrm{pH}$ air limbah hasil olahan IPAL sudah stabil dan netral sesuai dengan baku mutu yang ditetapkan.

Sesuai dengan Peraturan Menteri Lingkungan Hidup dan Kehutanan RI No. 5 tahun 2014 Lampiran XLVII tentang Baku Mutu Air Limbah bagi Usaha Dan/atau Kegiatan Yang Belum Memiliki Baku Mutu Air Limbah Yang Ditetapkan golongan II, maka dilakukan uji laboratorium terhadap hasil outlet IPAL PT Natura Perisa Aroma Lampung Selatan. Uji Laboratorium dilaksanakan setiap bulan untuk pengendalian baku mutu sesuai dengan yang dipersyaratkan. Hasil uji laboratorium sebagai berikut : 
Tabel 12. Hasil Uji Laboratorium IPAL PT Natura Perisa Aroma Lampung Selatan bulan Januari

\begin{tabular}{|c|c|c|c|}
\hline Parameter & Satuan & $\begin{array}{l}\text { Kadar } \\
\text { Maks }\end{array}$ & $\begin{array}{l}\text { Hasil } \\
\text { Outlet }\end{array}$ \\
\hline $\mathrm{pH}$ & - & $6-9$ & 7 \\
\hline TDS & $\mathrm{mg} / \mathrm{L}$ & 4000 & 166 \\
\hline TSS & $\mathrm{mg} / \mathrm{L}$ & 400 & 16 \\
\hline Fe & $\mathrm{mg} / \mathrm{L}$ & 10 & $<0.003$ \\
\hline Mn & $\mathrm{mg} / \mathrm{L}$ & 5 & $<0.003$ \\
\hline Cd & $\mathrm{mg} / \mathrm{L}$ & 0.1 & $<0.002$ \\
\hline $\mathrm{Hg}$ & $\mathrm{mg} / \mathrm{L}$ & 0.005 & $<0.0005$ \\
\hline $\mathrm{Pb}$ & $\mathrm{mg} / \mathrm{L}$ & 1 & $<0.004$ \\
\hline As & $\mathrm{mg} / \mathrm{L}$ & 0.5 & $<0.005$ \\
\hline Se & $\mathrm{mg} / \mathrm{L}$ & 0.5 & $<0.002$ \\
\hline $\mathrm{NH}_{3}-\mathrm{N}$ & $\mathrm{mg} / \mathrm{L}$ & 10 & 10 \\
\hline BODs & $\mathrm{mg} / \mathrm{L}$ & 150 & 13 \\
\hline COD & $\mathrm{mg} / \mathrm{L}$ & 300 & 56 \\
\hline Biru Metilen & $\mathrm{mg} / \mathrm{L}$ & 10 & 0.02 \\
\hline Fenol & $\mathrm{mg} / \mathrm{L}$ & 1 & $<0.001$ \\
\hline $\begin{array}{l}\text { Minyak \& } \\
\text { Lemak }\end{array}$ & $\mathrm{mg} / \mathrm{L}$ & 20 & $<1.8$ \\
\hline Temperatur & ${ }^{\circ} \mathrm{C}$ & 40 & 28 \\
\hline $\begin{aligned} \text { Sumber: } & \text { Hasil } \\
& \text { Peris } \\
& \text { Perd }\end{aligned}$ & $\begin{array}{l}\text { aborator } \\
\text { oma Bul }\end{array}$ & $\begin{array}{l}\text { Oulet If } \\
\text { lanuari } 2\end{array}$ & $\begin{array}{l}\text { PT Natur } \\
8 \text { UNILAB }\end{array}$ \\
\hline
\end{tabular}

\section{KESIMPULAN}

a. Limbah segar yang dihasilkan oleh proses produksi Unit Minyak Atsiri PT Natura Perisa Aroma Lampung Selatan bersifat asam dan memiliki temperatur yang tinggi sehingga perlu adanya unit proses netralisasi $\mathrm{pH}$ dan proses pendinginan sebelum masuk ke dalam Unit IPAL. Proses netralisasi menggunakan bahan kimia kaustik soda $(\mathrm{NaOH})$ dan proses pendinginan menggunakan proses pendinginan langsung dengan memperluas permukaan bak pengumpul.

b. Desain IPAL Industri PT Natura Perisa Aroma menggunakan reaktor lumpur aktif. Proses lumpur aktif termasuk proses biologis aerobik, yaitu proses penguraian polutan organik dalam air limbah dengan menggunakan mikroorganisme dan oksigen menjadi $\mathrm{CO}_{2}$ dan $\mathrm{H}_{2} \mathrm{O}, \mathrm{NH}_{4}$ dan sel biomassa baru.

c. Proses start-up IPAL dilakukan dengan memberikan mikroba (seeding) dan nutrisi ke dalam reaktor lumpur aktif selama 3 bulan secara bertahap sampai proses IPAL telah stabil.

d. Kegiatan monitoring dilaksanakan setelah start-up sistem IPAL PT Natura Perisa Aroma yang meliputi :

- Pengambilan sampel harian pada 5 titik pemantauan yaitu BP,LA, LS, LR, dan OS

- Pengukuran pH di setiap pengambilan sampel dan pengamatan endapan di sampel LA dan LR. Jika endapan tidak terbentuk sistem IPAL belum berjalan stabil.

- Melakukan uji laboratorium pada saat sistem IPAL PT Natura Perisa Aroma sudah stabil.

\section{DAFTAR PUSTAKA}

1. Said, N.I. (2000). "Pengolahan Air Limbah dengan Proses Biofilter Anaerob-Aerob". Jurnal Teknologi Lingkungan, BPPT. Jakarta.

2. Setiyono, Satmoko Yudo "Panduan Pengelolaan Instalasi Pengolahan Air Limbah Industri Otomotif' BPPT Press 2014.

3. Ir. Nusa Idaman Said, M.Eng, (2005) "Proses Dasar Dalam Pengolahan Limbah Cair"

4. Scherfig, J., and Mosharraf. F., Two-stage backwash system for wastewater filters using primary and final effluent. J. WPCF, 16511657, 1989.

5. Peraturan Menteri Lingkungan Hidup RI No. 5 tahun 2014 Lampiran XLVII tentang Baku Mutu Air Limbah bagi Usaha Dan/atau Kegiatan Yang Belum Memiliki Baku Mutu Air Limbah Yang Ditetapkan.

6. Kardinan, Agus. Tanaman Penghasil Minyak Atsiri. Jakarta 


\section{LAMPIRAN 1 :}

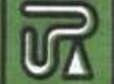

\section{PT. UNILAB PERDANA LABORATORIUM LINGKUNGAN HIDUP No. Reg. : OOO1/LPJILABLING-1/LRKIKLH}

Kantor Pusat : GEDUNG UNILAB , J. Ciledug Raya No. 10, Cipulir, Kebayoran Lama, Jakarta 12230 Telp. (021) 7253322 (hunting) Fax : 7253323 e-mail : unilabperdana@centrin.netid Kantor Pewakilan : Jl. Kuttisan IV/28, Kutisari, Tenggilis Mejoyo, Surabaya, Jawa Timur Teip. (031) 8415839 Fa. · (031) 8415839 e-mail : unilabperdana.surabaya@ggmail.com

\section{LAPORAN HASIL PENGUJIAN} Nomor : LPUP00265

Nama pelanggan

Alamat

No. identifikasi contoh Uraian contoh

Tanggal diterima di Lab

Tanggal pengujian
PT NATURA PERISA AROMA BANDAR LAMPUNG

Sukanegara, Bandar Lampung

00265-01

Air Limbah (inlet)

10 Januari 2018

: 10 Januari 2018 sampai 26 Januari 2018

Hasil penguilian

\begin{tabular}{|c|c|c|c|c|c|c|}
\hline \multirow{2}{*}{ No. } & \multirow{2}{*}{ PARAMETER: } & \multirow{2}{*}{ satuan } & \multicolumn{2}{|c|}{ GOLONGWH } & \multirow{2}{*}{ MASIL: } & \multirow{2}{*}{ METODE: } \\
\hline & & & 1 & 4 & & \\
\hline 1 & Zat Padat Terlarut (TDS) ${ }^{* *}$ ) & $\mathrm{mg} / \mathrm{l}$ & 2.000 & 4.000 & 57 & 18-6/KIA (Konduiktometri) \\
\hline 2 & Zat Padat Tersuspensi (TSS) ${ }^{* 7}$ ) & $\mathrm{mg} / \mathrm{L}$ & 200 & 400 & 68 & 18-7IIVIA (Spektrofotometri) \\
\hline 3. & $\mathrm{pH} * \mathrm{H}$ & - & \multicolumn{2}{|c|}{$\cdot$} & 4 & SNI 06-6989.11-2004 \\
\hline 4 & Besi Teriarut $(\mathrm{Fe})^{* n}$ ) & $m g / L$ & 5 & 10 & 0,1 & APHA Ed. 22nd 3120.8, 3030.8-2012 \\
\hline 5 & Mangan Terlarut $\left.(\mathrm{Mn})^{*}\right)$ & $\mathrm{mg} / \mathrm{l}$ & 2 & 5 & $<0,003$ & APHA Ed. 22nd 3120.B, 3030.B-2012 \\
\hline 6 & Kadmium $\left.(\mathrm{Cd})^{*}\right)$ & $\mathrm{mg} / \mathrm{l}$ & 0,05 & 0,1 & $<0,002$ & APHA Ed. 22 nd 3120. B, 3030.E-2012 \\
\hline 7 & Air Raksa ( $\mathrm{Hg}$ ) & $\mathrm{mg} / \mathrm{L}$ & 0,002 & 0,005 & $<0,0005$ & APHA Ed. 22nd 3112.8 - 2012 \\
\hline 8 & Timbal $(\mathrm{Pb}) *$ & $\mathrm{mg} / \mathrm{L}$ & 0,1 & 1 & $<0,004$ & APHA Ed. 22nd 3120.B, 3030.E-2012 \\
\hline 9 & Arsen (As) & $\mathrm{mg} / \mathrm{L}$ & 0,1 & 0,5 & $<0,005$ & APHA Ed. 22nd 3114.8 - 2012 \\
\hline 10 & Selenium ( $\mathrm{Se}$ ) & $\mathrm{mg} / \mathrm{L}$ & 0,05 & 0,5 & $<0,002$ & APHA Ed. 22nd 3114.8 - 2012 \\
\hline 11 & Amonia Nitrogen $\left.\left(\mathrm{NH}_{3}-\mathrm{N}\right)^{\mu 4}\right)$ & $\mathrm{mg} / \mathrm{l}$ & 5 & 10 & 0,3 & SNI 06-6989.30-2005 \\
\hline 12 & $\mathrm{BOD}_{5} \cdots$ & $\mathrm{mg} / \mathrm{L}$ & 50 & 150 & 107 & SNI $6989.72-2009$ \\
\hline 13 & $\left.\operatorname{COD}^{* *}\right)$ & $m g / l$. & 100 & 300 & 714 & SNI 00-6989.15-2004 \\
\hline 14 & Sernyawa aktif biru metllen ${ }^{* 0}$ ) & $\mathrm{mg} / \mathrm{h}$ & 5 & 10 & 0,04 & SNI 06-6989.51-2005 \\
\hline 15 & Fenol $\left.{ }^{* \infty}\right)$ & $m g / l$ & 0,5 & 1 & 3 & APHA Ed. 22nd 5530-Phenol.B-D-2012 \\
\hline 16 & Minyak \& Lemak " ") & $\mathrm{mg} / \mathrm{L}$ & 10 & 20 & 2 & SNI 6989.10-2011 \\
\hline
\end{tabular}

Jakarta, 30 Januari 2018

PT UNILAB PERDANA

Qhamms

Indri Hapsari $\ell$.

Kadiv. Operasional

Halaman 1 dari 2

- Hasil yang ditampilkan hanya berhubungan dengan contoh yang diuj dan laporan hasil pengujian tidak boleh

digandakan kecuali seluruhnya tanpa persetujuan tertulis dari laboratorium.

- Pengaduan terhadap laporan hasil pengujian tidak dilayani setelah 30 hari dari waiktu penerbitan laporan hasil pengujan 


\section{LAMPIRAN 2}

\section{PT. UNILAB PERDANA}

\section{LABORATORIUM LINGKUNGAN HIDUP}

No. REg. : O001/LPJILABLING-1/LRKIKLH

Kantor Pusat : GEDUNG UNILAB, JI Cledug Raya No, 10, Cipulir, Kebayoran Lama, Jakarta 12230 Telp. (021) 7253322 (hunting) Fax: 7253323 e-maill : unilabperdana Qcentrin.netid Kantor Perwaklan : Jl. Kutisan IV/2B, Kutisari, Tenggilis Mejoyo, Surabaya, Jawa Timur Telp. (031) 8415839 Far : (031) 8415839 e-mail : unilabperdana. surabaya@gmali.com

\section{LAPORAN HASIL PENGUJIAN}

\section{Nomor : LPUP00265}

Nama pelanggan

Alamat

PT NATURA PERISA AROMA

Sukanegara, Bandar Lampung

No. identifikasi contoh

Uraian contoh

00265-02

Tanggal diterima di Lab

Air Limbah (Outlet)

Tanggal pengujian

10 Januari 2018

10 Januari 2018 sampai 26 Januari 2018

Hasil penguilan

\begin{tabular}{|c|c|c|c|c|c|c|}
\hline \multirow{2}{*}{ No. } & \multirow{2}{*}{ PARAMETER } & \multirow{2}{*}{ SATUAN } & \multicolumn{2}{|c|}{ BOLONGAN 7} & \multirow{2}{*}{ Misil: } & \multirow{2}{*}{ MeTODE: } \\
\hline & & & t & in: & & \\
\hline 1 & Zat Padat Terlarut (TDS) ${ }^{* *}$ ) & $\mathrm{mg} / \mathrm{l}$ & 2.000 & 4.000 & 166 & 18-6/1KJA (Konduktometri) \\
\hline 2 & Zat Padat Tersuspensi (TSS) ") & $\mathrm{mg} / \mathrm{h}$ & 200 & 400 & 16 & 18-7nKVA (Spektrofotometri) \\
\hline 3 & $\left.\mathrm{pH}{ }^{*}\right)$ & $\cdot$ & \multicolumn{2}{|c|}{-} & 7 & SNI 06-6889.11-2004 \\
\hline 4 & Besi Teriarut $\left.(\mathrm{Fe})^{* *}\right)$ & $\mathrm{mg} / \mathrm{L}$ & 5 & 10 & $\infty, 003$ & APHA Ed. 22nd $3120 . B, 3030 . B-2012$ \\
\hline 5 & Mangan Terlarut $\left.(M n)^{* *}\right)$ & $\mathrm{mg} / \mathrm{l}$ & 2 & 5 & 40,003 & APHA Ed. 22nd 3120.8, 3030.B-2012 \\
\hline 8 & Kadmium (Cd) $\left.{ }^{* *}\right)$ & $\mathrm{mg} / \mathrm{L}$ & 0,05 & 0,1 & 4,002 & APHA Ed. 22nd 3120.B, $3030 . E-2012$ \\
\hline 7 & Air Raksa $(\mathrm{Hg})$ & $m g / l$ & 0,002 & 0,005 & $<0,0005$ & APHA Ed. 22nd 3112.B - 2012 \\
\hline 8 & Timbal $\left.(\mathrm{Pb})^{* *}\right)$ & $\mathrm{mg} / \mathrm{L}$ & 0,1 & 1 & $<0,004$ & APHA Ed. 22nd 3120.B, 3030.E-2012 \\
\hline 8 & Arsen (As) & $\mathrm{mg} / \mathrm{h}$ & 0,1 & 0,5 & 4,005 & APHA Ed. 22nd 3114.8 - 2012 \\
\hline 10 & Selenium (Se) & $\mathrm{mgl}$ & 0,05 & 0,5 & $<0,002$ & APHA Ed. 22nd $3114 . B$ - 2012 \\
\hline 11 & Amonia Nitrogen $\left(\mathrm{NH}_{3}-\mathrm{N}\right)^{\left.{ }^{* 4}\right)}$ & $\mathrm{mg} / \mathrm{L}$ & 5 & 10 & 10 & SNI 06-6889.30-2005 \\
\hline 12 & $\left.\mathrm{BOD}_{s}{ }^{* *}\right)$ & $\mathrm{mgl}$ & 50 & 150 & 13 & SNI 6889.72-2009 \\
\hline 13 & $\left.\cos ^{*}\right)$ & $\mathrm{mg} / \mathrm{L}$ & 100 & 300 & 56 & SNI 06-6838.15-2004 \\
\hline 14 & Sernyawa aldif biru metilen ") & $\mathrm{mg} / \mathrm{l}$ & 5 & 10 & 0,02 & SNI 06-6989.51-2005 \\
\hline 15 & Fenol $\left.{ }^{* \rightarrow}\right)$ & $\mathrm{mg} / \mathrm{h}$ & 0,5 & 1 & $<0,001$ & APHA Ed. 22nd 5530-Phenol,8-D-2012 \\
\hline 16 & Minyak \& Lemak *) & $\mathrm{mg} / \mathrm{l}$ & 10 & 20 & $<1,8$ & SN1 6889.10-2011 \\
\hline
\end{tabular}

Ket. : $"$ ) PERMENLHRINo. 5 Tahun 2014. Lampiran XLV

$" \eta$ ) Parameter terakrecitasi oleh KAN No. LP-195-IDN

$<=$ Lebih kecil

Jakarta, 30 Januari 2018

PT. UNILAB PERDANA<smiles>CCCCCCC</smiles>

ndri Hapsari $e$

Kadiv. Operasional

Halaman 2 dari 2

- Hasil yang ditampilikan hanya berhubungan dengan contoh yang diuj dan laporan hasil pengujaan tidak boleh

digandakan kecuali seluruhnya tanpa persetujuan tertulis dari laboratorium.

- Pengaduan terhadap laporan hasil pengujian tidak dilayani setelah 30 hari dari waktu penerbitan laporan hasil pengujlan 
LAMPIRAN 3

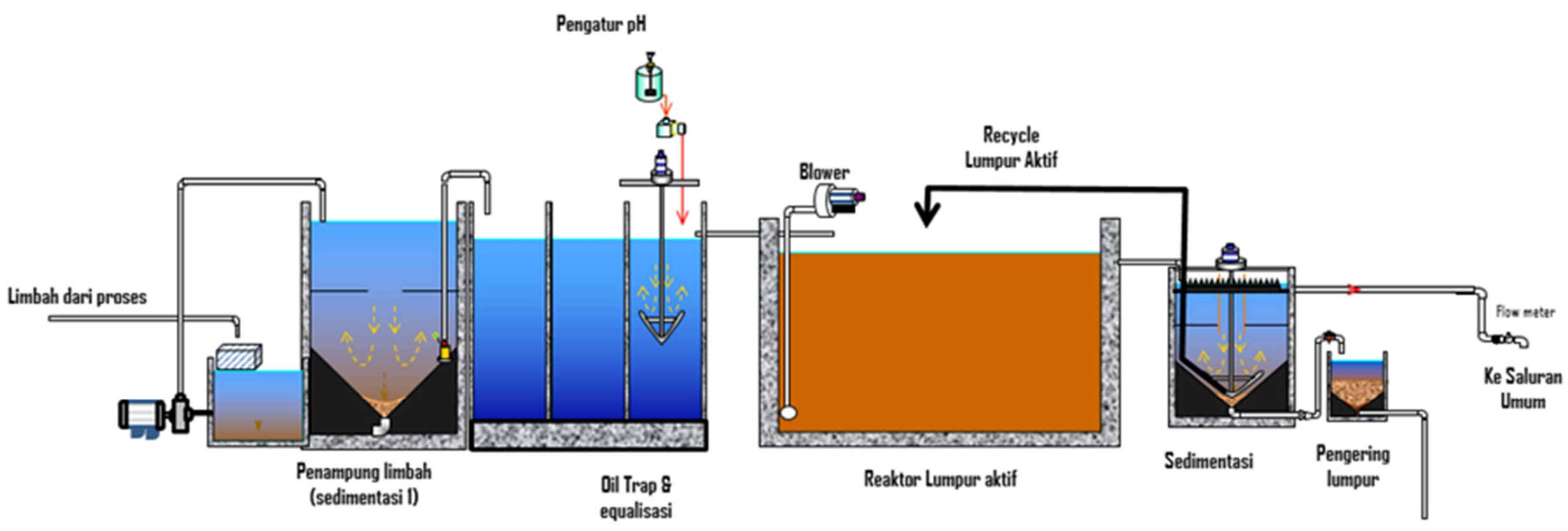

